\title{
Contribution of Anoctamins to Cell Survival and Cell Death
}

\author{
Karl Kunzelmann*(D), Jiraporn Ousingsawat, Roberta Benedetto, Ines Cabrita and \\ Rainer Schreiber
}

Institut für Physiologie, Universität Regensburg, Universitätsstraße 31, D-93053 Regensburg, Germany; Jiraporn.Ousingsawat@vkl.uni-regensburg.de (J.O.); Roberta.Benedetto@vkl.uni-regensburg.de (R.B.); Ines.Cabrita@vkl.uni-regensburg.de (I.C.); Rainer.Schreiber@vkl.uni-regensburg.de (R.S.)

* Correspondence: Karl.kunzelmann@ur.de; Tel.: +49-941-943-4302; Fax: +49-941-943-4315

Received: 19 February 2019; Accepted: 16 March 2019; Published: 19 March 2019

\begin{abstract}
Before anoctamins (TMEM16 proteins) were identified as a family of $\mathrm{Ca}^{2+}$-activated chloride channels and phospholipid scramblases, the founding member anoctamin 1 (ANO1, TMEM16A) was known as DOG1, a marker protein for gastrointestinal stromal tumors (GIST). Meanwhile, ANO1 has been examined in more detail, and the role of ANO1 in cell proliferation and the development of different types of malignomas is now well established. While ANO5, ANO7, and ANO9 may also be relevant for growth of cancers, evidence has been provided for a role of ANO6 (TMEM16F) in regulated cell death. The cellular mechanisms by which anoctamins control cell proliferation and cell death, respectively, are just emerging; however, the pronounced effects of anoctamins on intracellular $\mathrm{Ca}^{2+}$ levels are likely to play a significant role. Recent results suggest that some anoctamins control membrane exocytosis by setting $\mathrm{Ca}^{2+}{ }_{\mathrm{i}}$ levels near the plasma membrane, and/or by controlling the intracellular $\mathrm{Cl}^{-}$concentration. Exocytosis and increased membrane trafficking induced by ANO1 and ANO6 may enhance membrane expression of other chloride channels, such as CFTR and volume activated chloride channels (VRAC). Notably, ANO6-induced phospholipid scrambling with exposure of phosphatidylserine is pivotal for the sheddase function of disintegrin and metalloproteinase (ADAM). This may support cell death and tumorigenic activity of IL-6 by inducing IL-6 trans-signaling. The reported anticancer effects of the anthelminthic drug niclosamide are probably related to the potent inhibitory effect on ANO1, apart from inducing cell cycle arrest through the Let-7d/CDC34 axis. On the contrary, pronounced activation of ANO6 due to a large increase in intracellular calcium, activation of phospholipase A2 or lipid peroxidation, can lead to ferroptotic death of cancer cells. It therefore appears reasonable to search for both inhibitors and potent activators of TMEM16 in order to interfere with cancer growth and metastasis.
\end{abstract}

Keywords: anoctamin; ANO1; ANO6; TMEM16A; TMEM16F; cancer; proliferation; apoptosis; $\mathrm{Ca}^{2+}$ signaling; inflammation

\section{Introduction}

$\mathrm{Cl}^{-}$currents activated by an increase in intracellular $\mathrm{Ca}^{2+}(\mathrm{CaCC})$ have been known for more than 40 years. The human homologue of Drosophila tweety and the bestrophin family of channels were shown to operate as $\mathrm{Ca}^{2+}$ activated $\mathrm{Cl}^{-}$channels (reviewed in [1-3]). However, they behave differently from the "classical" receptor-operated CaCC, identified 11 years ago as anoctamin 1 (ANO1; TMEM16A) [4-6]. ANO1 is particularly expressed in acinar cells of secretory glands and is regulated by CLCA1 $[7,8]$. Apart from glands, CaCCs have long been known to be present primarily in proliferating cells in culture and various types of cancer cells [9-11]. After identification of ANO1 as $\mathrm{Ca}^{2+}$ activated $\mathrm{Cl}^{-}$channel, it became clear that the protein is identical to DOG1, a significant and 
reliable tumor marker in gastrointestinal stromal tumors (GIST) and head and neck cancers [12-14] (Table 1). Meanwhile, ANO1 has been found in a number of different malignant tumors. Apart from ANO1, other members of the anoctamin family were also correlated with cell proliferation and cancer development, like ANO5 (TMEM16E), ANO7 (TMEM16G) and ANO9 (TMEM16J) (Table 1). Anoctamins could have tumor-specific functions, or may support cell proliferation and possible development towards malignancy in any cell-type. The latter assumption is supported by the fact that ANO1 is present in many different types of proliferating cells and tumor tissues [15] (Table 1). Notably, the ANO1-knockout mouse is hypotrophic when compared to wild type littermates [16]. ANO1 and its role in proliferation and cancer development has been reported repeatedly, but we are still far from any comprehensive understanding. Compared to Ano1, much less is known for other anoctamin paralogues regarding their potential role in proliferation and tumor development (Table 1). Moreover, some anoctamins, like ANO6, may even promote cell death, rather than growth.

Table 1. Anoctamins in Cancer and Proliferation.

\begin{tabular}{|c|c|}
\hline Anoctamin Paralogue & References \\
\hline \multicolumn{2}{|l|}{ Anoctamin 1, TMEM16A } \\
\hline GIST, squamous carcinoma, head and neck cancer & {$[12-14,17-41]$} \\
\hline Pancreatic cancer & [42-44] \\
\hline Prostate cancer & {$[45-47]$} \\
\hline Breast cancer & [48-53] \\
\hline Colorectal carcinoma & {$[54,55]$} \\
\hline Gastric cancer & {$[56,57]$} \\
\hline Glioma, Glioblastoma & {$[58,59]$} \\
\hline Esophageal cancer & {$[60]$} \\
\hline Lung cancer & {$[61-63]$} \\
\hline Hepatocellular carcinoma & {$[64]$} \\
\hline \multicolumn{2}{|l|}{ Ovarian cancer } \\
\hline Liposarcoma & [65] \\
\hline Leimyosarcoma & {$[66]$} \\
\hline Salivary gland cancer & [67] \\
\hline Chondroblastoma & [68] \\
\hline General role in cancer and proliferation & {$[14,69-76]$} \\
\hline \multicolumn{2}{|l|}{ Anoctamin 5, TMEM16E } \\
\hline Colorectal cancer & {$[77,78]$} \\
\hline Thyroid cancer & [79] \\
\hline \multicolumn{2}{|l|}{ Anoctamin 6, TMEM16F } \\
\hline Myoblast proliferation & [80] \\
\hline \multicolumn{2}{|l|}{ Anoctamin 7, TMEM16G } \\
\hline Prostate cancer & [81-86] \\
\hline Breast cancer & [87] \\
\hline \multicolumn{2}{|l|}{ Anoctamin 9, TMEM16J } \\
\hline Pancreatic cancer & [88] \\
\hline Colorectal carcinoma & [89] \\
\hline
\end{tabular}

\section{Anoctamins and Their Cellular Localization}

Anoctamins form a family of $\mathrm{Ca}^{2+}$-activated proteins, consisting of phospholipid scramblases and ion channels [90,91]. The 10 proteins (ANO1-10; TMEM16A-K) are broadly expressed in epithelial and non-epithelia tissues [15]. ANO1 appears to operate as a relatively selective anion channel [92], while ANO6 is a phospholipid scramblase, i.e., it moves phosphatidylserine from the inner to the outer plasma membrane leaflet, when activated by a large increase in intracellular $\mathrm{Ca}^{2+}[93,94]$. However, ANO6 is also permeable for chloride ions [95-97]. Previous work suggests that it becomes increasingly 
nonselective with increasing concentrations of intracellular free $\mathrm{Ca}^{2+}$ [98]. Although it is now clear that most anoctamins operate as phospholipid scramblases [99-101], our earlier work may suggest that all anoctamins also conduct ions, when co-expressed with purinergic receptors and activated by stimulation with ATP [102]. A subsequent study on the role of ANO5 for muscle repair presented strong evidence that ANO5 is a scramblase and conducts ions as well [103].

It is not entirely clear to what extent anoctamins operate as channels/scramblases in the apical plasma membrane of polarized cells, and what fraction of the protein resides in intracellular membranous compartments, or in the basolateral plasma membrane. For example, ANO1 is apical in pancreas, salivary gland, and airways, but it is basolateral in mouse colonic epithelia [104-107]. Cellular location of ANO1 may therefore depend on the cell type, and maybe on the cell function and differentiation. For example, ANO5 is mostly found intracellularly, but it can be also detected in the plasma membrane where it produces a non-selective whole cell current $[15,102]$. Endogenous and overexpressed ANO10 is typically intracellular, and co-localizes with acetylated tubulin [108-110]. However, expression and localization appears tissue dependent and may dependent on the cell cycle. For example, endogenous ANO10 in rapidly proliferating Fisher Rat Thyroid (FTR) cells is mostly intracellular and appears upregulated during mitosis [108] (Figure 1). Once FRT cells form a dense monolayer and stop proliferating in serum free media, some ANO10 moves into the cell membrane and co-localizes with the centrioles [108] (Figure 1A). Non-proliferating cells on permeable supports and in the absence of serum seem to lower expression of ANO10, which is now preferentially expressed close to the centriole and probably in the primary cilium (Figure 1). Expression in the primary cilium has also been observed for ANO1 and ANO6 in renal and retinal pigment epithelial cells [111-113]. We may therefore hypothesize a dynamic regulation of expression and localization of anoctamins, depending on proliferation and on the cell cycle (Figure 1B). As discussed below, upregulation of ANO1 is correlated with enhanced proliferation, e.g., in polycystic kidney disease, in many rapidly growing cell lines, as well as in different types of tumors [73,114] (Table 1).

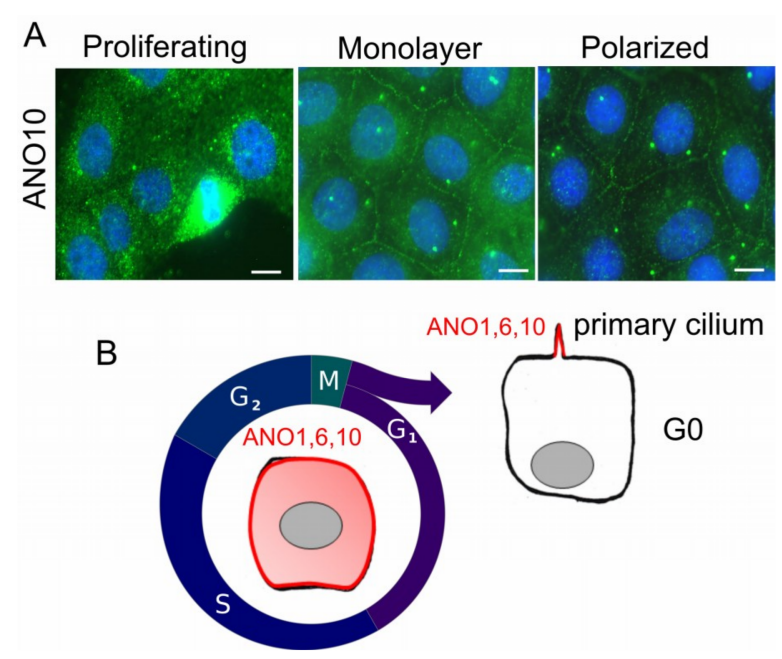

Figure 1. Proliferation-dependent expression of ANO10 in FRT cells. (A) FRT cells were grown in FCS-containing media at 70\% density (Proliferating), as confluent monolayer in FCS-free media (Monolayer), or as polarized monolayer on permeable supports and in FCS-free media (Polarized). Expression of endogenous ANO10 (green fluorescence) was intracellular in dividing cells (Proliferating), but was detected in the plasma membrane and in the primary cilium in densely grown cells (Monolayer). ANO10 was more prominent in plasma membrane and primary cilium in polarized cells (Polarized). For further details and references, see main text. (B) Hypothetical model proposing variable cellular locations of ANO10 depending on cell proliferation or cell polarization. ANO10 is found primarily intracellularly, but is also in the plasma membrane during cell cycle. Reduced expression of ANO10 and translocation into the primary cilium is observed once cells move into $\mathrm{G}_{0}$. Bar, $20 \mu \mathrm{m}$ [108]. 


\section{How Is ANO1 Upregulated during Cell Proliferation and Cancer Development?}

Most studies on ANO1 have been performed on cultured cells, particularly in ANO1 overexpressing cells. Under these conditions, ANO1 currents are generally of large size and may show some properties that are different to currents expressed endogenously [95,115]. Although ANO1 is widely expressed and particularly abundant in epithelial cells $[15,90,91]$, we observed that non-proliferating epithelial cells in culture or freshly isolated (non-cultured) cells from airways, kidney and intestine show very little $\mathrm{Ca}^{2+}$ activated $\mathrm{Cl}^{-}$currents [116-118]. However, ANO1 currents are quickly upregulated once cells have been isolated from the tissue and are maintained in serum-containing media under proliferating conditions. Upregulation of ANO1-currents can be reversed by growing the cells on permeable supports and removing the serum so that cells stop proliferating $[11,106,116,117,119,120]$. Thus, removing the cells from their physiological environment, cellular reorganization and pro-mitotic stimulation may all contribute to upregulation of ANO1. Moreover, transcriptional stimulation via the IL4/IL13-Jack-STAT3-STAT6 axis, steroid hormones such as testosterone, activation of histone deacetylase (HDCA), promotor hypo- methylation, as well as downregulation of inhibitory micro-RNAs have been shown to upregulate ANO1 expression (reviewed in $[73,74,76,121,122]$ (Figure 2).

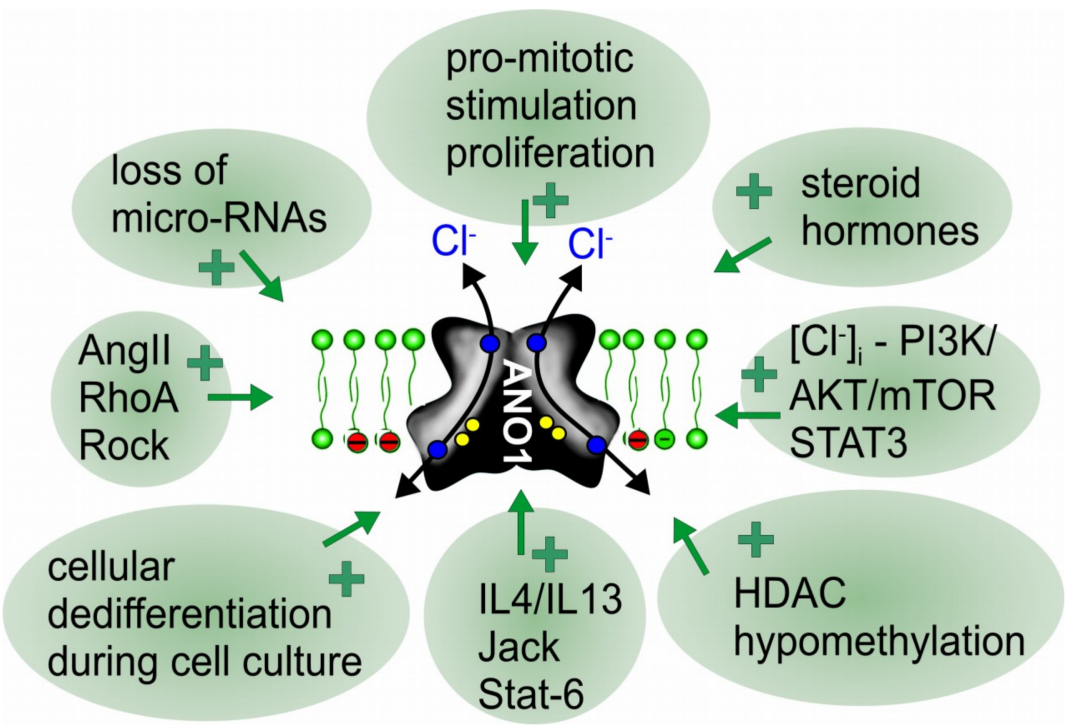

Figure 2. Upregulation and redistribution of ANO1 during proliferation and cancer. Scheme summarizing reported factors and signaling pathways that lead to upregulation of expression of ANO1 and cellular redistribution during proliferation and cancer growth (Table 1). For further details and references, see main text.

\section{ANO1, Cell Proliferation and Tumor Growth: How Does It Work?}

ANO1 was found to increase proliferation in many different tissues [14,26,30,71,72,75,114,123-125] (Table 1). Apart from increasing proliferation, additional pro-apoptotic effects of ANO1 have also been reported, based on studies using ANO1-inhibitors. It should be noted, however, that ANO1-inhibitors might exert non-specific effects, when used at higher concentrations. In contrast, inhibition of proliferation by knockout of ANO1-expression or inhibition of ANO1 using low concentrations of ANO1 inhibitors have been shown in a number of studies $[73,126,127]$. This can also be demonstrated in experiments using nanomolar concentrations of the recently identified potent ANO1 inhibitor niclosamide, which however, has a number of additional anti-cancer effects (c.f. below) [128]. Nevertheless, other ANO1-inhibitors also blocked cell proliferation and cancer growth [30,72,127,129].

Niclosamide is a FDA-approved drug and was shown to inhibit Notch signaling [130], a pathway that is well known to participate in tumorigenesis [131]. In a number of reports, additional 
antineoplastic mechanisms of niclosamide have been described. Thus, niclosamide was shown to inhibit nuclear factor kappa B (NF-kB), Wnt/B-catenin signaling, the IL-6-JAK1-STAT3-pathway, GSK-3 and more [132-140]. A recent paper suggests cell cycle arrest by niclosamide, through activation of the Let-7d/CDC34 axis [41]. Notably, blockade of notch signaling inhibits goblet cell metaplasia in asthmatic mice, which could be part of the mechanism how niclosamide inhibits mucus production $[128,141,142]$. Moreover, mucus production is also inhibited by other ANO1 inhibitors, such as niflumic acid (NFA) and CaCCinhAO1, or in ANO1 knockout mice $[107,143,144]$. Although the antiproliferative effects of niclosamide correspond well to its inhibitory effect on ANO1, this relationship is not well recognized. Niclosamide has been used in a number of preclinical studies and even in clinical trials with prostate and colorectal cancer patients [135,137,145-149]. Taken together, the multiple anti-cancer effects described for the ANO1-inhibitor niclosamide, may correspond to the wide range of pro-cancerous mechanisms by ANO1 (Figure 3).

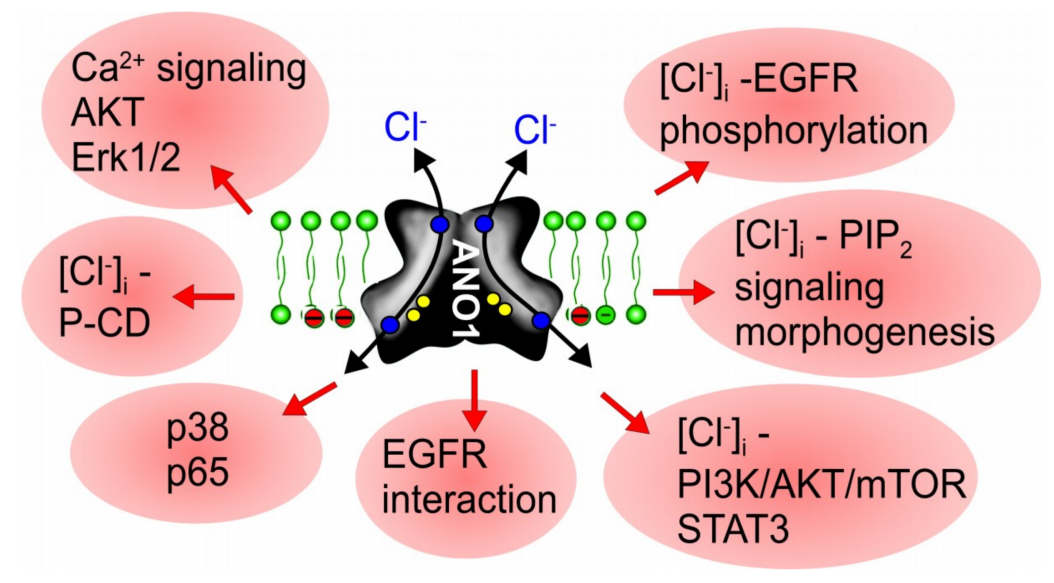

Figure 3. Mechanisms for ANO1-induced cell proliferation and cancer development. Scheme summarizing reported mechanisms for ANO1-induced cell proliferation and development of cancer. All pathways are inhibited by niclosamide and other inhibitors of anoctamins (Table 1). For further details and references, see main text.

\section{ANO5, 6, 7, and 9 in Cancer and Cell Proliferation}

Other members of the anoctamin family were also associated with cell proliferation, embryogenesis and cancer growth. ANO5 (TMEM16E) is now known for its role in myoblast proliferation and muscle repair [80,103], while gain of function mutations of ANO5 cause gnathodiaphyseal dysplasia [150]. In a collaborative effort, we identified an essential role of ANO6 for embryogenesis [151]. Similar to ANO5 also ANO6 was also reported to control myoblast proliferation [80]. ANO7 (TMEM16G, NGEP) is a marker for prostate cancer [85,86]. For ANO9 (TMEM16J) an inverse correlation of expression and progression of colorectal cancer was described [89], while it may also promote pancreatic cancer [88]. Interestingly, enhanced phospho-Erk1,2 activity was correlated with the cellular effects of ANO1, 6, and 9, but a possible common mechanism remains obscure $[30,80,88]$.

\section{Anoctamins Control Intracellular $\mathrm{Ca}^{2+}$ Levels}

Growth hormone receptors signal via Ras/Raf/Erk1,2, PI3K/Akt, and DAG/IP 3 [152], while intracellular $\mathrm{Ca}^{2+}$ signals are essential regulators of cell proliferation [153]. We showed that anoctamins control compartmentalized $\mathrm{Ca}^{2+}$ signals $\left(\left[\mathrm{Ca}^{2+}\right]_{\mathrm{i}}\right)$, and therefore proposed this as a major mechanism by which ANO1, and possibly other anoctamins, affect cell proliferation and a number of other cellular properties $[108,110,154,155]$. It is important to note that ANO1 is homologous to yeast Ist2, known to tether the peripheral cortical endoplasmic reticulum (ER) to the plasma membrane [156]. Gamper and collaborators convincingly showed that the relatively low $\mathrm{Ca}^{2+}$ sensitivity of ANO1 at 
(physiological) negative membrane voltages, requires this mechanism in order to concentrate $\mathrm{Ca}^{2+}$ near the plasma membrane and in close proximity of ANO1 [157,158]. ER-localized inositol trisphosphate receptors interact with ANO1 and tether the ER to ANO1 containing plasma membranes [157]. Moreover, IP3-induced $\mathrm{Ca}^{2+}$ store release is augmented by ANO1 [110]. Anoctamin-controlled $\mathrm{Ca}^{2+}$ compartments could be relevant for expression and activation of Erk1,2 [30,159]. Transient rise in intracellular $\mathrm{Ca}^{2+}$ followed by sustained activation of the Ras/Raf/Erk pathway is a central aspect of cell proliferation in many systems [154,160-162].

Although detailed mechanisms are currently not fully understood, it is clear that also other anoctamins affect $\left[\mathrm{Ca}^{2+}\right]_{i}$, i.e., basal $\left[\mathrm{Ca}^{2+}\right]_{i}$ as well as receptor mediated $\mathrm{Ca}^{2+}$ signals depend on expression of anoctamins [110]. Apart from compartmentalization, protein interaction [163] and membrane depolarization, anoctamins may also contribute to cell proliferation and cell growth by operating as counter-ion channels. Counter ion movement of $\mathrm{K}^{+}$or $\mathrm{Cl}^{-}$over the ER membrane is necessary for charge compensation to allow for efficient $\mathrm{Ca}^{2+}$ transport out of the ER via release channels, and for re-uptake of $\mathrm{Ca}^{2+}$ into the ER by the sarcoplasmic endoplasmic reticulum $\mathrm{Ca}^{2+}$-ATPase (SERCA) [164,165]. Given the $\mathrm{Ca}^{2+}$ permeability of some anoctamins, they may also serve as plasma membrane localized $\mathrm{Ca}^{2+}$ channels $[90,166-168]$ or ER $\mathrm{Ca}^{2+}$ leakage channels [103,110,154,169-171]. Disturbed intracellular $\mathrm{Ca}^{2+}$ signals with changes of cellular properties are detectable in naïve tissues and primary cells from mice with knockout of anoctamins [107,108,110,155,172-174] (Figure 4).

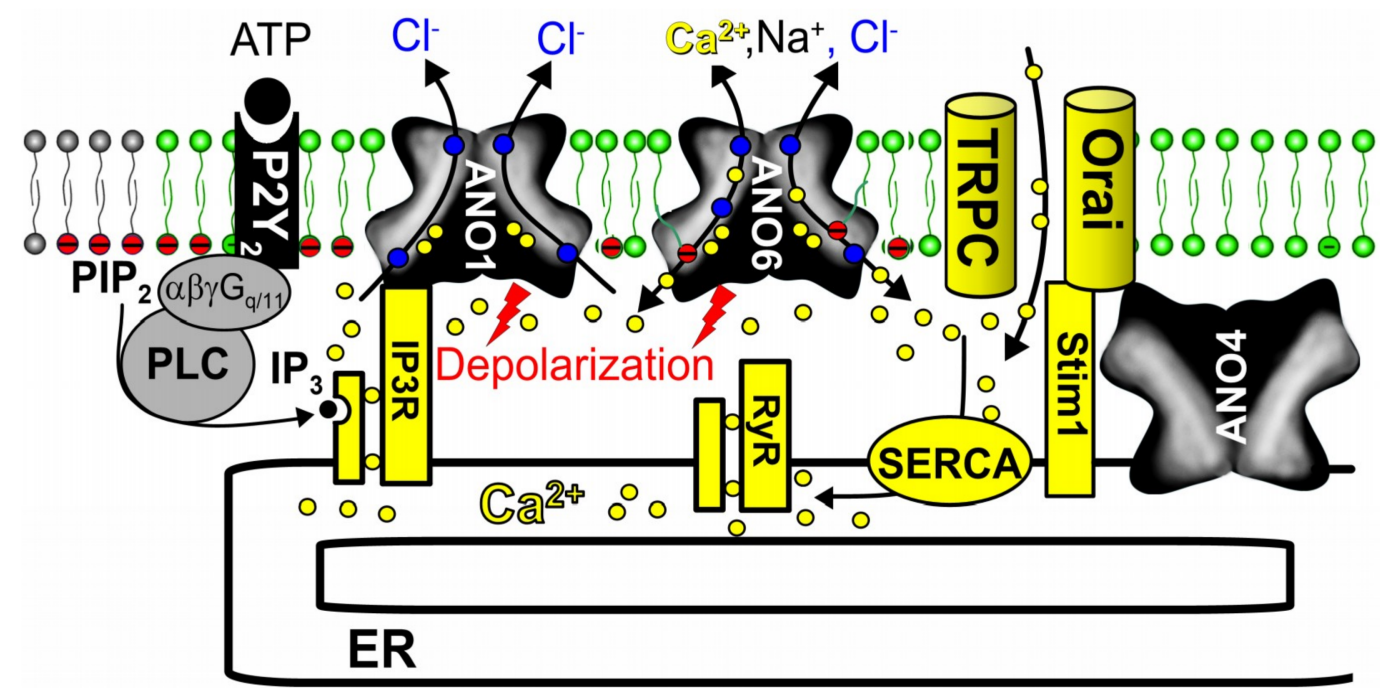

Figure 4. Compartmentalized $\mathrm{Ca}^{2+}$ signaling by anoctamins. Scheme illustrating the effects of anoctamins on $\mathrm{Ca}^{2+}$ signaling. ANO1 tethers ER Ca ${ }^{2+}$ stores close to the plasma membrane, which leads to improved ATP-induced apical $\mathrm{Ca}^{2+}$ signaling. Activation of both ANO1 and ANO6 induce plasma membrane depolarization, supporting release of $\mathrm{Ca}^{2+}$ from ER stores via inositol trisphosphate receptors $\left(\mathrm{IP}_{3} \mathrm{R}\right)$ and ryanodine receptors $(\mathrm{RyR})$. In addition, $\mathrm{Ca}^{2+}$ store content was found to be enhanced by ANO1. ANO6 is permeable for $\mathrm{Ca}^{2+}$ and therefore supports $\mathrm{Ca}^{2+}$ entry. ANO4 localized in the ER interacts with Orai1 [110]. For further details and references, see main text.

\section{The Role of Anoctamins in Controlling Intracellular $\mathrm{Cl}^{-}$Concentration, Exocytosis, Organ Growth and Microvesicular Signaling}

Recent reports suggest additional mechanisms whereby anoctamins may augment proliferation and cell growth. He and coworkers proposed an interesting concept in which ANO1 controls cytoplasmic $\mathrm{Cl}^{-}$levels that affect phosphoinositide levels in the inner plasma membrane leaflet, such as PtdIns(4,5)P2 in membrane microdomains [175]. Although the proposed concept requires further validation, it could contribute to attenuated purinergic $\mathrm{Ca}^{2+}$ signals found in tissues isolated from conditional ANO1 knockout animals or in ANO1 knockout cells (c.f. above). Similar to He 
et al., we also detected shortened motile cilia in the respiratory epithelium of ANO1-knockout mice, as well as a reduced length of non-motile primary cilia in renal collecting ducts of ANO1 knockout mice. While motile cilia from wt animals measured $6.1 \pm 0.4 \mu \mathrm{m}$, those from animals with a ANO1-knockout in ciliated epithelial cells had a length of only $3.6 \pm 0.4 \mu \mathrm{m}(\mathrm{n}=7)$. Finally, the data by Ruppersburg and Hartzell convincingly demonstrate the importance of ANO1 for primary ciliogenesis [111]. siRNA-suppression of ANO6 expression and expression of other anoctamins suggested a contribution to basal $\mathrm{Cl}^{-}$conductance [102]. In contrast, overexpression of ANO1 and ANO6 enhanced basal $\mathrm{Cl}^{-}$conductance when analyzed at $37^{\circ} \mathrm{C}$ [95]. In contrast to He et al., we found that ongoing activation of ANO1 (or ANO6) by either ionomycin or purinergic stimulation increased intracellular $\mathrm{Cl}^{-}$concentrations in HEK293 and HeLa cells [102]. Nevertheless the proposed concept that intracellular $\mathrm{Cl}^{-}$levels determine vesicular endocytosis/exocytosis, control apical membrane delivery and morphogenesis [175], is interesting and corresponds well to the role of ANO1 in exocytosis and normal renal development detected in recent studies [107,175-177] (Figure 5). It is also noteworthy that intracellular $\mathrm{Cl}^{-}$regulation by ANO1 has been shown to participate in transcription of human epidermal growth factor receptor 2, which mediates PI3K/AKT/mTOR and JAK/STAT3 signaling pathways [52].

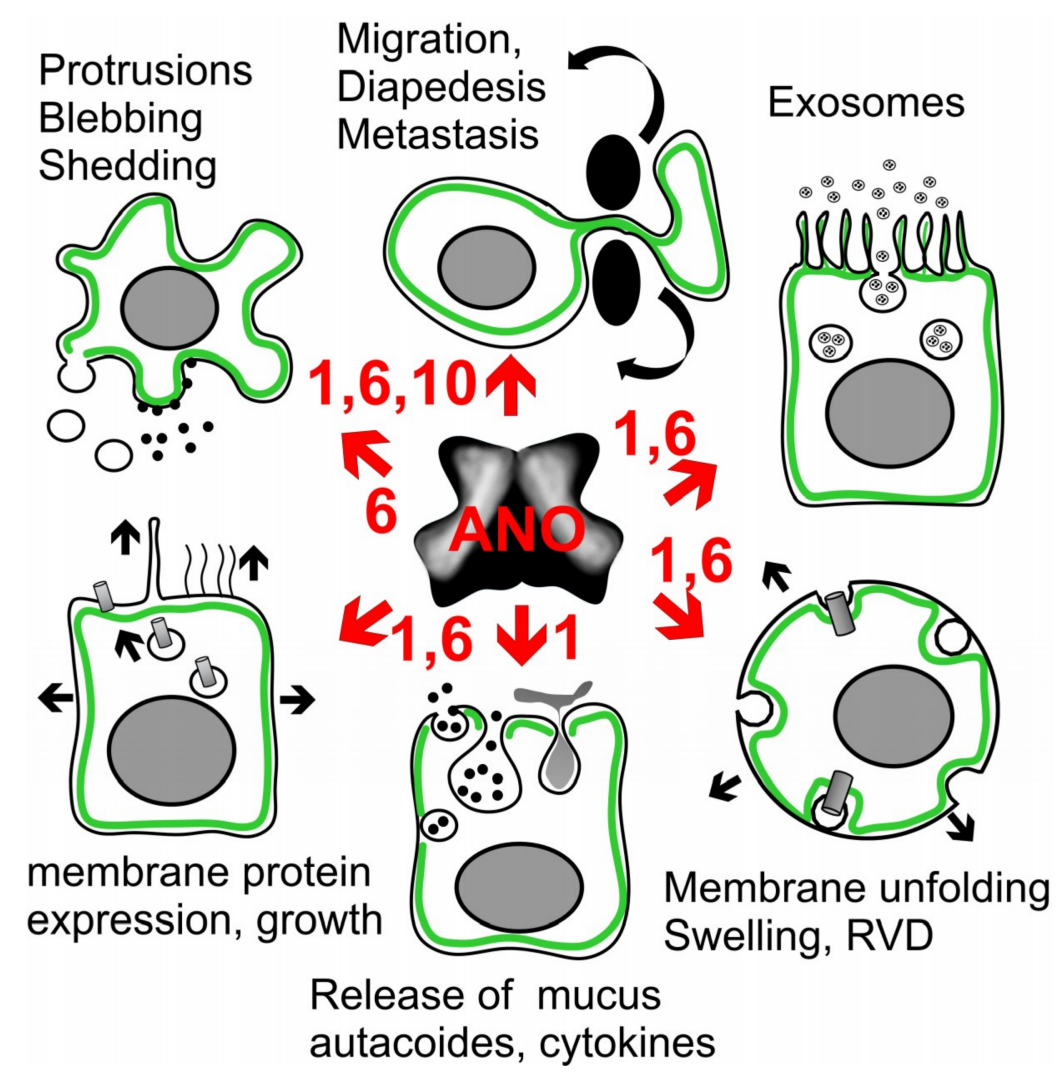

Figure 5. Potential action of anoctamins on exocytosis, growth and microvesicular signaling. ANO1 and ANO6 determine the extent of membrane protrusions and membrane blebbing in macrophages and other cell types, and support cell migration, diapedesis and cancer metastasis. Exosome release and paracrine signaling by epithelial cells is probably anoctamin-dependent. Support of membrane unfolding, cell swelling and subsequent activation of VRAC could be a general property of anoctamins. Mucus secretion and release of inflammatory mediators such as autacoids and cytokines was shown to be ANO1-dependent. Exocytosis leads to enhanced expression of membrane proteins, cell growth, and extensions such as motile cilia and the primary cilium, as proposed for ANO1. For further details and references, see main text. 
We observed that animals lacking expression of ANO1 in epithelial cells of airways and intestine accumulate mucus in club (Clara) and goblet cells [107]. We found that ANO1 is essential for secretion of mucus, probably by controlling mucus release from club/goblet cells, and by controlling release of prosecretory cytokines from ciliated cells [107]. IL-13-induced production and secretion of Muc5AC was inhibited by the ANO1 blocker and antiproliferative/anticancer drug, niclosamide. Along the same line, release of IL-8 induced by lipopolysaccharide (LPS) was significantly reduced by knockdown of ANO1. A recent paper by Hilgemann and colleagues demonstrates massive membrane expansion with activation of ANO6, with subsequent membrane shedding [178]. These results are reminiscent to our earlier observations of ANO6-depending blebbing and membrane shedding in macrophages [98]. Taken together, there is now evidence that anoctamins, particularly ANO1 and ANO6, control endolysosomal trafficking $[98,107,108,175,179,180]$, membrane exocytosis, increase in membrane surface area and insertion of proteins into the plasma membrane $[155,176,181]$ (Figure 5). As outlined above, ANO1 and ANO6 control $\left[\mathrm{Ca}^{2+}\right]_{\mathrm{i}}$, which is an essential regulator of exocytosis. Thus compartmentalized $\left[\mathrm{Ca}^{2+}\right]_{\mathrm{i}}$ close to the plasma membrane is required for docking of exocytic vesicles and granules, respectively. This process requires the so-called Munc13 proteins and the soluble $\mathrm{N}$-ethylmaleimide-sensitive factor-attachment protein receptor machinery [182,183].

Anoctamins were shown to have additional impact on cancer related events that involve plasma membrane function. Both ANO1 and ANO6 support cell migration and metastasis [14,26,30,55,61,73,184]. Endogenous ANO6 expressed in macrophages, or ANO6 overexpressed in HEK293 cells, induced massive membrane blebbing when activated by the P2X-agonist ATP [98]. ANO6 also supported apoptosis, movement, and formation of protrusions, as well as phagocytic activity and bacterial killing by macrophages $[98,108]$. Importantly, phosphatidylserine exposure by ANO6 is required for the function of ADAM17 and ADAM10, both members of the family of cell bound disintegrin and metalloproteases. These enzymes regulate a plethora of biological functions, including proliferation and cell death [185-187]. The role of ANO1 for organ development, cell growth and extension of motile cilia and primary cilia has been discussed above. This is in line with its contribution to exocytosis and release of mucus or cytokines [107,155,176,188,189]. Moreover, other papers report a function of ANO6 [178] and ANO1 [190] for the release of microvesicles and exosomes, which could represent a paracrine control of neighbor cells in airways and intestine [107,191-194]. Notably, ANO1 is excreted in human urinary exosomes [195]. Interestingly, for both tissue repair [196] and necroptotic cell death [197] a role of the endosomal-sorting complex required for transport (ESCRT) has been described. Correspondingly, repair of muscle membrane requires ANO5 [103,198], while ANO6 has a role in necroptotic cell death $[197,199]$. Finally, our previous work suggests a role of ANO1, ANO6 and ANO10 in both membrane swelling and volume regulation by regulatory volume decrease, which is related to membrane unfolding and phospholipid metabolism [109,176,200] (Figure 5). This will be described in more detail below.

\section{ANO1 Is Upregulated during Inflammation}

The current data suggest that upregulated ANO1 in rapidly growing cells and tumors, supports proliferation, while expression in differentiated non-proliferating cells is generally much lower and may enable cells to perform specific tasks such as signaling, contraction, or secretion of electrolytes and mucus. Proliferation and inflammation/hypoxia are intimately connected through multiple signaling pathways including JACK/STAT [201-203]. Thus, it is not surprising that ANO1 is strongly upregulated during inflammation, which enabled its molecular identification as CaCC [6,204]. ANO1 is strongly upregulated in inflammatory airway diseases such as CF, COPD and asthma, which parallels goblet cell metaplasia and mucus hypersecretion $[143,181,205]$. It is also upregulated during bacterial inflammation [206]. Upregulation of TMEM16A is predominant in mucus producing cells and to a lesser degree in ciliated airway epithelial cells $[107,155,205,207]$. ANO1 may participate in the 
transition from inflammation to proliferation, which explains its strong impact in wound healing and tissue repair $[14,103,208]$.

\section{Relationship of Anoctamins to the Tumor Associated $\mathrm{Cl}^{-}$Channel VRAC}

All living cells are able to maintain a constant cell volume. According to a general concept, regulatory volume decrease (RVD) prevents cell swelling and necrotic cell death, while regulatory volume increase (RVI) prevents cell shrinkage and apoptotic cell death $[209,210]$. The volume regulated or swelling activated anion channel (VRAC) is activated during RVD. Excessive activation of VRAC may support apoptotic cell death, while its upregulation leads to cellular resistance towards anti-cancer drugs [209,211-217]. Recent experiments suggest that ANO1 and ANO6 also contribute to volume activated whole cell currents, which may indicate a possible functional link between anoctamins and VRAC [123,176,200,218]. Although broadly expressed, there has been a long controversy concerning the molecular identity of VRAC, which was finally solved in 2014 [219-221]. Structural analysis by cryo-EM demonstrated a hexameric assembly of LRRC8 subunits, which form a typical ion channel with a central pore, structurally related to the connexin family of channels [222-224]. Conserved charged amino acid residues at the extracellular domain determine the permeability towards anions and other osmolytes. Two structurally different populations of VRAC have been shown by Kasuya et al., corresponding to a compact and a relaxed conformation. These conformations may correlate to closed and open states of the channel [224].

Although rather abundant, LRRC8/VRAC may not be essential for RVD and thus cells may be able to control their cell volume in the absence of VRAC [225-227]. Lack of functional VRAC leads to increased prenatal and postnatal mortality, growth retardation, and multiple tissue abnormalities, including abnormal function of B- and T-cells [228-231]. Additional, LRRC8-independent and cell-specific mechanisms may exist that enable RVD. These mechanisms comprise other $\mathrm{Cl}^{-} \mathrm{channels}$ such CFTR, bestrophin, and anoctamins, as well as electroneutral $\mathrm{KCl}$ co-transporter [218,225-227]. An inverse relationship exists between the magnitudes of VRAC and of $\mathrm{Ca}^{2+}$ activated $\mathrm{ANO} 1 \mathrm{Cl}^{-}$currents: With increased activation of CaCC, VRAC decreases and vice versa [232,233]. We could not activate ANO1 after maximal activation of VRAC [123], while Zholos et al showed a reduced probability for activation of VRAC after activation of CaCC [233]. A loss of expression of LRRC8A not only inhibited VRAC, but also attenuated $\mathrm{Ca}^{2+}$ activated $\mathrm{Cl}^{-}$currents. Vice versa, overexpression of LRRC8A enhanced $\mathrm{Ca}^{2+}$ activated $\mathrm{Cl}^{-}$currents. Because LRRC8A and ANO1 could be co-immunoprecipitated, a co-localization of both anion channels is proposed, with membrane insertion of LRRC8A being supported by ANO1 [176]. Apart from ANO1 and ANO6, also VRAC is blocked by niclosamide [95]. Because VRAC induces resistance towards cisplatin and other anticancer drugs and leads to metastasis and bad patient outcome, inhibition of VRAC may be another mechanism how niclosamide inhibits growth of cancer $[215,234,235]$.

Taken together, a functional relationship exists between VRAC and ANO1, possibly because activation of both channels involves release of $\mathrm{Ca}^{2+}$ from the ER-store [200,236]. As VRAC controls survival of cells, the functional crosstalk with ANO1 is highly relevant for tumor biology $[215,234,236]$.

\section{Role of Anoctamins in Cell Death}

Sustained large increase in intracellular $\mathrm{Ca}^{2+}$ can lead to senescence or cell death $[237,238]$. We showed earlier that $\mathrm{P} 2 \mathrm{X}_{7}$-mediated increase of intracellular $\mathrm{Ca}^{2+}$ leads to cell death of macrophages and lymphocytes expressing endogenous ANO6, and of HEK293 cells overexpressing ANO6 [98,239]. ANO6 is a component of the so-called outwardly rectifying $\mathrm{Cl}^{-}$channel ORCC or ICOR, and has a role in cell shrinkage and programmed cell death [218,239-241]. Expression of ANO6 is dominant in the surface epithelium of large intestine, were aged enterocytes die and dead cells are exfoliated. ANO6 is not found in intestinal crypts, where enterocytes are produced from stem cells [239]. TUNEL assays performed in mouse intestinal epithelium lacking ANO6 expression, unmask reduced cell death, when compared to wt mice. In addition, ANO10 is important for spontaneous and TNF $\alpha$-induced cell death 
in mouse intestinal epithelium, peritoneal macrophages, and THP1 macrophages [108]. Moreover, knockdown of ANO6 impaired apoptosis and formation of cyst lumen in 3D cultures of MDCK renal cysts. ANO6 is normally expressed in apoptotic cells within the center of growing cysts formed by MDCK cells and human polycystic kidneys [113].

Although many studies demonstrated the pro-proliferative role of ANO1, a pro-apoptotic function of ANO1 has also been reported [125,242,243]. Almaca et all showed that activation of ANO1 can lead to apoptotic cell shrinkage [123]. Interestingly, the genes for ANO1 and for apoptosis associated Fas associated via death domain (FADD), are located on a common amplicon located on chromosome 11q13. Surprisingly, both proteins were associated with better survival of HNSCC patients [38]. In contrast to ANO1, which is unable to scramble membrane phospholipids, ANO6-induced cell death is probably related to its ability to scramble membrane phospholipid [99]. Interestingly, we found that expression of ANO1 enhanced ionomycin-induced scrambling performed by endogenous ANO6 in HEK293 cells. This may point to a synergism between both anoctamins, which has also been detected earlier for $\mathrm{Cl}^{-}$ currents produced by both proteins [244].

Meanwhile, a number of independent regulated cell death pathways have been identified [245]. Initially, ANO6 has been reported in the context of apoptosis, but is now shown to be activated also during necroptosis, pyroptosis and ferroptosis [95,199,246-248]. Thus, activation of anoctamins, particularly of ANO6, might be a possibility to induce cell death in cancer cells.

\section{Activation of Anoctamins and Ferroptotic Cell Death in Cancer}

Pro-apoptotic $\mathrm{Cl}^{-}$currents have been activated in cells overexpressing ANO1, ANO6, ANO9 and ANO10 [95,123,227]. A potent activator of anoctamins is the bee venom melittin, which stimulates phospholipase A2 (PLA $)[95,200]$. Noteworthy, melittin has been widely used as anti-cancer therapy, and $\mathrm{PLA}_{2}$-dependent activation of metalloproteinase is essential for this effect [249-251].

Anoctamins are also activated through reactive oxygen species and by lipid peroxidation. This may lead to inflammation and proliferation, ion secretion and ferroptosis, depending on the cell type, the anoctamin paralogue being activated, and the strength of peroxidation $[95,118,247,252,253]$. Ferroptosis is induced by accumulation of intracellular iron, and is distinct from apoptosis, necrosis, and other forms of regulated cell death [254]. Ferroptosis is triggered by an increase in reactive oxygen species (ROS) and an overwhelming lipid peroxidation that ultimately leads to cell death by disintegration of the plasma membrane. Experimentally lipid peroxidation is also induced by erastin-inhibition of cysteine import through the transporter system $\mathrm{X}_{\mathrm{c}}{ }^{-}$. This leads to depletion of glutathione (GSH) and inactivation of the phospholipid peroxidase glutathione peroxidase 4 (GPX4). In addition, GPX4 can be directly inhibited by RSL3 [255].

Cell death can be induced in cancer cells by activation of ANO6 through melittin-induced PLA 2 or through lipid peroxidation [95]. This may suggest a new potential therapeutic approach to inhibit growth of cancer $[95,247]$. Lipid peroxidation and ferroptosis-induced cell death was proposed earlier as a mechanism to destroy cancer cells [256]. However, the ROS buffer capacity is typically quite high in cancer cells, which will antagonize lipid peroxidation [257]. ROS levels could be enhanced to exceed the antioxidant defense of cancer cells [258]. A number of preclinical studies were performed using small molecules to inhibit cellular glutathione antioxidant activity [259-262]. Tumor cell lines that were killed by the ANO6-activator melittin were also driven into ferroptosis by erastin and RSL3. Thus ANO1 and ANO6 were shown to be activated during ferroptotic cell death [118,247].

\section{Conclusions}

Proteins of the anoctamin/TMEM16 family scramble membrane phospholipids and operate as $\mathrm{Cl}^{-}$and cation-permeable channels. They demonstrate impressive effects on basic cell properties, and support both cell proliferation and regulated cell death. Clearly more work is required to be able to define the cellular functions of anoctamins, and their role in proliferation and cancer development. Despite the plethora of underlying cell specific signaling pathways, it will be interesting to learn 
whether common mechanisms exist for the cellular effects induced by anoctamins, such as enhanced intracellular $\mathrm{Ca}^{2+}$ signaling. Blocking ANO1 appears feasible to interfere with cancer growth.

In contrast to the pro-proliferative effect of ANO1, ANO6 seem to contribute to different types of regulated cell death (Figure 6). Activation of ANO6 may cause swelling or shrinkage of cells, and does increase in intracellular $\mathrm{Ca}^{2+}$, phospholipid scrambling, membrane blebbing and membrane shedding. It may all contribute to ANO6-induced cell death. Thus, direct activation of ANO6 may be a promising new strategy to induce cell death in cancer cells.

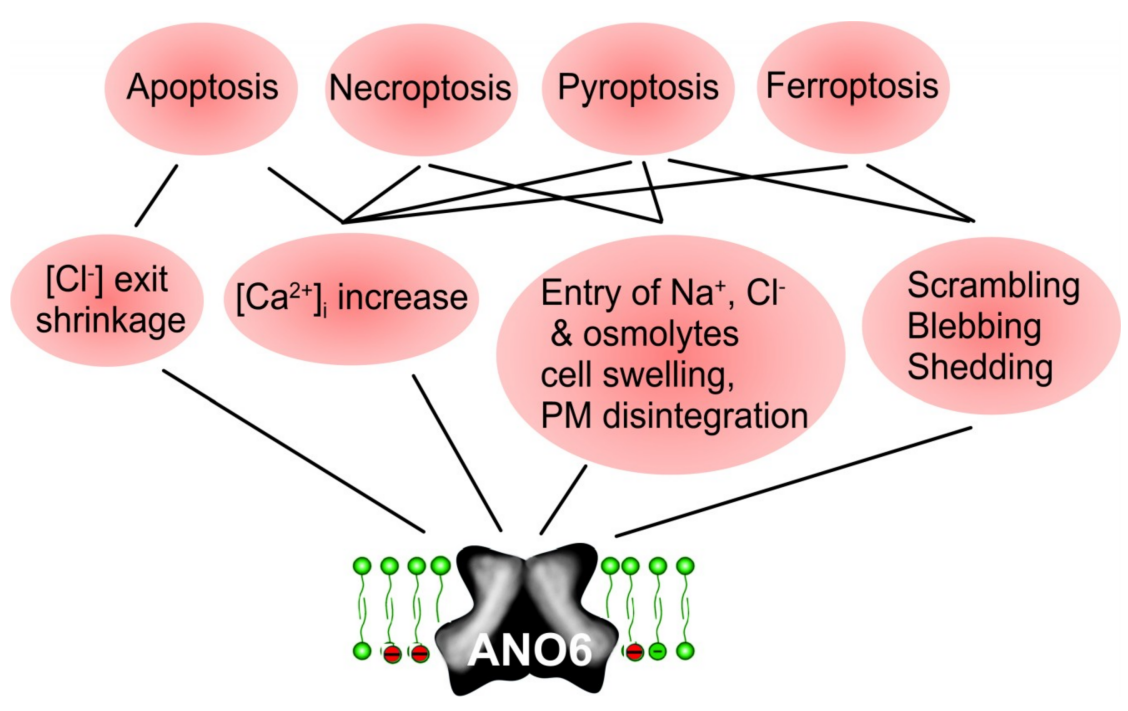

Figure 6. ANO6-induced cell death. Scheme summarizing the contribution of ANO6 to different regulated cell death pathways such as apoptosis, necroptosis, pyroptosis, and ferroptosis. Anoctamins may contribute to regulated cell death by cell shrinkage (apoptosis), increase in compartmentalized intracellular $\mathrm{Ca}^{2+}$ (all cell death pathways), or cell swelling, scrambling, blebbing, and membrane disintegration (ferroptosis, pyroptosis). For further details and references, see main text.

Funding: This research was funded by the Deutsche Forschungsgemeinschaft DFG KU756/14-1, DFG-Projektnummer 387509280-SFB 1350, Cystic Fibrosis Trust SRC 013, Sander Stiftung and Mukoviszidose Institute.

Conflicts of Interest: The authors declare that the research was conducted in the absence of any commercial or financial relationships that could be construed as a potential conflict of interest.

\section{References}

1. Hartzell, H.C.; Yu, K.; Xiao, Q.; Chien, L.T.; Qu, Z. Anoctamin/TMEM16 family members are Ca ${ }^{2+}$-activated Cl-channels. J. Physiol. 2008, 587, 2127-2139. [CrossRef] [PubMed]

2. Eggermont, J. Calcium-activated chloride channels: (un)known, (un)loved? Proc. Am. Thorac. Soc. 2004, 1, 22-27. [CrossRef] [PubMed]

3. Kunzelmann, K.; Kongsuphol, P.; Chootip, K.; Toledo, C.; Martins, J.R.; Almaca, J.; Tian, Y.; Witzgall, R.; Ousingsawat, J.; Schreiber, R. Role of the $\mathrm{Ca}(2+)$-activated $\mathrm{Cl}(-)$ channels bestrophin and anoctamin in epithelial cells. Biol. Chem. 2011, 392, 125-134. [CrossRef] [PubMed]

4. Yang, Y.D.; Cho, H.; Koo, J.Y.; Tak, M.H.; Cho, Y.; Shim, W.S.; Park, S.P.; Lee, J.; Lee, B.; Kim, B.M.; et al. TMEM16A confers receptor-activated calcium-dependent chloride conductance. Nature 2008, 455, 1210-1215. [CrossRef] [PubMed]

5. Schroeder, B.C.; Cheng, T.; Jan, Y.N.; Jan, L.Y. Expression cloning of TMEM16A as a calcium-activated chloride channel subunit. Cell 2008, 134, 1019-1029. [CrossRef]

6. Caputo, A.; Caci, E.; Ferrera, L.; Pedemonte, N.; Barsanti, C.; Sondo, E.; Pfeffer, U.; Ravazzolo, R.; Zegarra-Moran, O.; Galietta, L.J. TMEM16A, A Membrane Protein Associated With Calcium-Dependent Chloride Channel Activity. Science 2008, 322, 590-594. [CrossRef] 
7. Sala-Rabanal, M.; Yurtsever, Z.; Nichols, C.G.; Brett, T.J. Secreted CLCA1 modulates TMEM16A to activate $\mathrm{Ca}(2+)$-dependent chloride currents in human cells. Elife 2015, 4, e05875. [CrossRef]

8. Loewen, M.E.; Forsyth, G.W. Structure and function of CLCA proteins. Physiol. Rev. 2005, 85, 1061-1092. [CrossRef]

9. Hartzell, H.C.; Putzier, I.; Arreola, J. Calcium-Activated Chloride Channels. Annu. Rev. Physiol. 2005, 67, 719-758. [CrossRef]

10. Schreiber, R. Ca ${ }^{2+}$ signaling, intracellular $\mathrm{pH}$ and cell volume in cell proliferation. J. Membr. Biol. 2005, 205, 129-137. [CrossRef]

11. Kunzelmann, K. Ion channels and cancer. J. Membr. Biol. 2005, 205, 159-173. [CrossRef]

12. Espinosa, I.; Lee, C.H.; Kim, M.K.; Rouse, B.T.; Subramanian, S.; Montgomery, K.; Varma, S.; Corless, C.L.; Heinrich, M.C.; Smith, K.S.; et al. A novel monoclonal antibody against DOG1 is a sensitive and specific marker for gastrointestinal stromal tumors. Am. J. Surg. Pathol. 2008, 32, 210-218. [CrossRef]

13. West, R.B.; Corless, C.L.; Chen, X.; Rubin, B.P.; Subramanian, S.; Montgomery, K.; Zhu, S.; Ball, C.A.; Nielsen, T.O.; Patel, R.; et al. The novel marker, DOG1, is expressed ubiquitously in gastrointestinal stromal tumors irrespective of KIT or PDGFRA mutation status. Am. J. Pathol. 2004, 165, 107-113. [CrossRef]

14. Ruiz, C.; Martins, J.R.; Rudin, F.; Schneider, S.; Dietsche, T.; Fischer, C.A.; Tornillo, L.; Terracciano, L.M.; Schreiber, R.; Bubendorf, L.; et al. Enhanced Expression of ANO1 in Head and Neck Squamous Cell Carcinoma Causes Cell Migration and Correlates with Poor Prognosis. PLoS ONE 2012, 7, e43265. [CrossRef]

15. Schreiber, R.; Uliyakina, I.; Kongsuphol, P.; Warth, R.; Mirza, M.; Martins, J.R.; Kunzelmann, K. Expression and Function of Epithelial Anoctamins. J. Biol. Chem. 2010, 285, 7838-7845. [CrossRef]

16. Kunzelmann, K.; Schreiber, R.; Kmit, A.; Jantarajit, W.; Martins, J.R.; Faria, D.; Kongsuphol, P.; Ousingsawat, J.; Tian, Y. Expression and function of epithelial anoctamins. Exp. Physiol. 2012, 97, 184-192. [CrossRef]

17. Carles, A.; Millon, R.; Cromer, A.; Ganguli, G.; Lemaire, F.; Young, J.; Wasylyk, C.; Muller, D.; Schultz, I.; Rabouel, Y.; et al. Head and neck squamous cell carcinoma transcriptome analysis by comprehensive validated differential display. Oncogene 2006, 25, 1821-1831. [CrossRef]

18. Carneiro, A.; Isinger, A.; Karlsson, A.; Johansson, J.; Jonsson, G.; Bendahl, P.O.; Falkenback, D.; Halvarsson, B.; Nilbert, M. Prognostic impact of array-based genomic profiles in esophageal squamous cell cancer. BMC Cancer 2008, 8, 98. [CrossRef]

19. Liegl, B.; Hornick, J.L.; Corless, C.L.; Fletcher, C.D. Monoclonal antibody DOG1.1 shows higher sensitivity than KIT in the diagnosis of gastrointestinal stromal tumors, including unusual subtypes. Am. J. Surg. Pathol. 2009, 33, 437-446. [CrossRef]

20. Miwa, S.; Nakajima, T.; Murai, Y.; Takano, Y.; Sugiyama, T. Mutation assay of the novel gene DOG1 in gastrointestinal stromal tumors (GISTs). J. Gastroenterol. 2008, 43, 531-537. [CrossRef]

21. Fatima, N.; Cohen, C.; Siddiqui, M.T. DOG1 utility in diagnosing gastrointestinal stromal tumors on fine-needle aspiration. Cancer Cytopathol. 2011, 119, 202-208. [CrossRef]

22. Kang, G.H.; Srivastava, A.; Kim, Y.E.; Park, H.J.; Park, C.K.; Sohn, T.S.; Kim, S.; Kang, D.Y.; Kim, K.M. DOG1 and PKC-theta are useful in the diagnosis of KIT-negative gastrointestinal stromal tumors. Modern Pathol. 2011, 24, 866-875. [CrossRef]

23. Hwang, D.G.; Qian, X.; Hornick, J.L. DOG1 antibody is a highly sensitive and specific marker for gastrointestinal stromal tumors in cytology cell blocks. Am. J. Clin. Pathol. 2011, 135, 448-453. [CrossRef]

24. Novelli, M.; Rossi, S.; Rodriguez-Justo, M.; Taniere, P.; Seddon, B.; Toffolatti, L.; Sartor, C.; Hogendoorn, P.C.; Sciot, R.; Van Glabbeke, M.; et al. DOG1 and CD117 are the antibodies of choice in the diagnosis of gastrointestinal stromal tumours. Histopathology 2010, 57, 259-270. [CrossRef]

25. Wong, N.A.; Shelley-Fraser, G. Specificity of DOG1 (K9 clone) and protein kinase C theta (clone 27) as immunohistochemical markers of gastrointestinal stromal tumour. Histopathology 2010, 57, 250-258. [CrossRef]

26. Ayoub, C.; Wasylyk, C.; Li, Y.; Thomas, E.; Marisa, L.; Robe, A.; Roux, M.; Abecassis, J.; de Reynies, A.; Wasylyk, B. ANO1 amplification and expression in HNSCC with a high propensity for future distant metastasis and its functions in HNSCC cell lines. Br. J. Cancer 2010, 103, 715-726. [CrossRef]

27. Lee, C.H.; Liang, C.W.; Espinosa, I. The utility of discovered on gastrointestinal stromal tumor 1 (DOG1) antibody in surgical pathology-the GIST of it. Adv. Anat. Pathol. 2010, 17, 222-232. [CrossRef]

28. Kleist, B.; Lasota, J.; Miettinen, M. Gastrointestinal stromal tumor and gastric adenocarcinoma collision tumors. Hum. Pathol. 2010, 41, 1034-1039. [CrossRef] 
29. Miettinen, M.; Wang, Z.F.; Lasota, J. DOG1 antibody in the differential diagnosis of gastrointestinal stromal tumors: A study of 1840 cases. Am. J. Surg. Pathol. 2009, 33, 1401-1408. [CrossRef]

30. Duvvuri, U.; Shiwarski, D.J.; Xiao, D.; Bertrand, C.; Huang, X.; Edinger, R.S.; Rock, J.R.; Harfe, B.D.; Henson, B.J.; Kunzelmann, K.; et al. TMEM16A, induces MAPK and contributes directly to tumorigenesis and cancer progression. Cancer Res. 2012, 72, 3270-3281. [CrossRef]

31. Yamamoto, H.; Kojima, A.; Nagata, S.; Tomita, Y.; Takahashi, S.; Oda, Y. KIT-negative gastrointestinal stromal tumor of the abdominal soft tissue: A clinicopathologic and genetic study of 10 cases. Am. J. Surg. Pathol. 2011, 35, 1287-1295. [CrossRef]

32. Li, Y.; Zhang, J.; Hong, S. ANO1 as a marker of oral squamous cell carcinoma and silencing ANO1 suppresses migration of human SCC-25 cells. Med. Oral Patol. Oral Cir. Bucal 2014, 19, e313-e319. [CrossRef]

33. Simon, S.; Grabellus, F.; Ferrera, L.; Galietta, L.; Schwindenhammer, B.; Muhlenberg, T.; Taeger, G.; Eilers, G.; Treckmann, J.; Breitenbuecher, F.; et al. DOG1 regulates growth and IGFBP5 in gastrointestinal stromal tumors. Cancer Res. 2013, 73, 3661-3670. [CrossRef]

34. Berglund, E.; Akcakaya, P.; Berglund, D.; Karlsson, F.; Vukojevic, V.; Lee, L.; Bogdanovic, D.; Lui, W.O.; Larsson, C.; Zedenius, J.; et al. Functional role of the Ca-activated Cl channel DOG1/TMEM16A in gastrointestinal stromal tumor cells. Exp. Cell Res. 2014, 326, 315-325. [CrossRef]

35. Slavik, T.; du Plessis, J.; Sparaco, A.; van der Merwe, S.W. Duodenal gastrointestinal stromal tumor with epithelioid and neural features mimicking a primary pancreas head neuroendocrine tumor. Pancreas 2014, 43, 482-483. [CrossRef]

36. Rodrigo, J.P.; Menendez, S.T.; Hermida-Prado, F.; Alvarez-Teijeiro, S.; Villaronga, M.A.; Alonso-Duran, L.; Vallina, A.; Martinez-Camblor, P.; Astudillo, A.; Suarez, C.; et al. Clinical significance of Anoctamin-1 gene at $11 \mathrm{q} 13$ in the development and progression of head and neck squamous cell carcinomas. Sci. Rep. 2015, 5, 15698. [CrossRef]

37. Bill, A.; Gutierrez, A.; Kulkarni, S.; Kemp, C.; Bonenfant, D.; Voshol, H.; Duvvuri, U.; Gaither, L.A. ANO1/TMEM16A interacts with EGFR and correlates with sensitivity to EGFR-targeting therapy in head and neck cancer. Oncotarget 2015, 6, 9173-9188. [CrossRef]

38. Reddy, R.B.; Bhat, A.R.; James, B.L.; Govindan, S.V.; Mathew, R.; Ravindra, D.R.; Hedne, N.; Illiayaraja, J.; Kekatpure, V.; Khora, S.S.; et al. Meta-Analyses of Microarray Datasets Identifies ANO1 and FADD as Prognostic Markers of Head and Neck Cancer. PLoS ONE 2016, 11, e0147409. [CrossRef]

39. Dixit, R.; Kemp, C.; Kulich, S.; Seethala, R.; Chiosea, S.; Ling, S.; Ha, P.K.; Duvvuri, U. TMEM16A/ANO1 is differentially expressed in HPV-negative versus HPV-positive head and neck squamous cell carcinoma through promoter methylation. Sci. Rep. 2015, 5, 16657. [CrossRef]

40. Godse, N.R.; Khan, N.I.; Yochum, Z.A.; Gomez-Casal, R.; Kemp, C.; Shiwarski, D.J.; Seethala, R.; Kulich, S.; Seshadri, M.; Burns, T.F.; et al. TMEM16A/ANO1 inhibits apoptosis via down-regulation of Bim expression. Clin. Cancer Res. 2017. [CrossRef]

41. Han, Z.; Li, Q.; Wang, Y.; Wang, L.; Li, X.; Ge, N.; Wang, Y.; Guo, C. Niclosamide Induces Cell Cycle Arrest in G1 Phase in Head and Neck Squamous Cell Carcinoma Through Let-7d/CDC34 Axis. Front. Pharmacol. 2018, 9, 1544. [CrossRef]

42. Ardeleanu, C.; Arsene, D.; Hinescu, M.; Andrei, F.; Gutu, D.; Luca, L.; Popescu, L.M. Pancreatic Expression of DOG1: A Novel Gastrointestinal Stromal Tumor (GIST) Biomarker. Appl. Immunohistochem. Mol. Morphol. 2009, 17, 413-418. [CrossRef]

43. Bergmann, F.; Andrulis, M.; Hartwig, W.; Penzel, R.; Gaida, M.M.; Herpel, E.; Schirmacher, P.; Mechtersheimer, G. Discovered on gastrointestinal stromal tumor 1 (DOG1) is expressed in pancreatic centroacinar cells and in solid-pseudopapillary neoplasms-novel evidence for a histogenetic relationship. Hum. Pathol. 2011, in press. [CrossRef]

44. Sauter, D.R.; Novak, I.; Pedersen, S.F.; Larsen, E.H.; Hoffmann, E.K. ANO1 (TMEM16A) in pancreatic ductal adenocarcinoma (PDAC). Pflug. Arch. 2014, 467, 1495-1508. [CrossRef]

45. Liu, W.; Lu, M.; Liu, B.; Huang, Y.; Wang, K. Inhibition of Ca(2+)-activated Cl(-) channel ANO1/TMEM16A expression suppresses tumor growth and invasiveness in human prostate carcinoma. Cancer Lett. 2012, 326, 41-51. [CrossRef]

46. Seo, Y.; Ryu, K.; Park, J.; Jeon, D.K.; Jo, S.; Lee, H.K.; Namkung, W. Inhibition of ANO1 by luteolin and its cytotoxicity in human prostate cancer PC-3 cells. PLoS ONE 2017, 12, e0174935. [CrossRef] 
47. Song, Y.; Gao, J.; Guan, L.; Chen, X.; Gao, J.; Wang, K. Inhibition of ANO1/TMEM16A induces apoptosis in human prostate carcinoma cells by activating TNF-alpha signaling. Cell Death Dis. 2018, 9, 703. [CrossRef]

48. Ubby, I.; Bussani, E.; Colonna, A.; Stacul, G.; Locatelli, M.; Scudieri, P.; Galietta, L.J.; Pagani, F. TMEM16A alternative splicing coordination in breast cancer. Mol. Cancer 2013, 12, 75. [CrossRef]

49. Britschgi, A.; Bill, A.; Brinkhaus, H.; Rothwell, C.; Clay, I.; Duss, S.; Rebhan, M.; Raman, P.; Guy, C.T.; Wetzel, K.; et al. Calcium-activated chloride channel ANO1 promotes breast cancer progression by activating EGFR and CAMK signaling. Proc. Natl. Acad. Sci. USA 2013, 110, E1026-E1034. [CrossRef]

50. Wu, H.; Guan, S.; Sun, M.; Yu, Z.; Zhao, L.; He, M.; Zhao, H.; Yao, W.; Wang, E.; Jin, F.; et al. Ano1/TMEM16A Overexpression Is Associated with Good Prognosis in PR-Positive or HER2-Negative Breast Cancer Patients following Tamoxifen Treatment. PLoS ONE 2015, 10, e0126128. [CrossRef]

51. Cheng, H.; Yang, S.; Qu, Z.; Zhou, S.; Ruan, Q. Novel Use for DOG1 in Discriminating Breast Invasive Carcinoma from Noninvasive Breast Lesions. Dis. Mark. 2016, 2016, 5628176. [CrossRef]

52. Fujimoto, M.; Inoue, T.; Kito, H.; Niwa, S.; Suzuki, T.; Muraki, K.; Ohya, S. Transcriptional repression of HER2 by ANO1 Cl(-) channel inhibition in human breast cancer cells with resistance to trastuzumab. Biochem. Biophys. Res. Commun. 2017, 482, 188-194. [CrossRef]

53. Wu, H.; Wang, H.; Guan, S.; Zhang, J.; Chen, Q.; Wang, X.; Ma, K.; Zhao, P.; Zhao, H.; Yao, W.; et al. Cell-specific regulation of proliferation by Ano1/TMEM16A in breast cancer with different ER, PR, and HER2 status. Oncotarget 2017. [CrossRef]

54. Foda, A.A.; Mohamed, M.A. Aberrant expressions of c-KIT and DOG-1 in mucinous and nonmucinous colorectal carcinomas and relation to clinicopathologic features and prognosis. Ann. Diagn. Pathol. 2015, 19, 335-340. [CrossRef]

55. Sui, Y.; Sun, M.; Wu, F.; Yang, L.; Di, W.; Zhang, G.; Zhong, L.; Ma, Z.; Zheng, J.; Fang, X.; et al. Inhibition of TMEM16A Expression Suppresses Growth and Invasion in Human Colorectal Cancer Cells. PLoS ONE 2014, 9, e115443. [CrossRef]

56. Liu, F.; Cao, Q.H.; Lu, J.; Luo, B.; Lu, X.F.; Luo, R.C.; Wang, X.G. TMEM16A overexpression contributes to tumor invasion and poor prognosis of human gastric cancer through TGF-beta signaling. Oncotarget 2015, 6, 11585-11599.

57. Cao, Q.; Liu, F.; Ji, K.; Liu, N.; He, Y.; Zhang, W.; Wang, L. MicroRNA-381 inhibits the metastasis of gastric cancer by targeting TMEM16A expression. J. Exp. Clin. Cancer Res. 2017, 36, 29. [CrossRef]

58. Liu, J.; Liu, Y.; Ren, Y.; Kang, L.; Zhang, L. Transmembrane protein with unknown function 16A overexpression promotes glioma formation through the nuclear factor-kappaB signaling pathway. Mol. Med. Rep. 2014, 9, 1068-1074. [CrossRef]

59. Lee, Y.S.; Lee, J.K.; Bae, Y.; Lee, B.S.; Kim, E.; Cho, C.H.; Ryoo, K.; Yoo, J.; Kim, C.H.; Yi, G.S.; et al. Suppression of 14-3-3gamma-mediated surface expression of ANO1 inhibits cancer progression of glioblastoma cells. Sci. Rep. 2016, 6, 26413. [CrossRef]

60. Shang, L.; Hao, J.J.; Zhao, X.K.; He, J.Z.; Shi, Z.Z.; Liu, H.J.; Wu, L.F.; Jiang, Y.Y.; Shi, F.; Yang, H.; et al. ANO1 protein as a potential biomarker for esophageal cancer prognosis and precancerous lesion development prediction. Oncotarget 2016, 10, 24374. [CrossRef]

61. Jia, L.; Liu, W.; Guan, L.; Lu, M.; Wang, K. Inhibition of Calcium-Activated Chloride Channel ANO1/TMEM16A Suppresses Tumor Growth and Invasion in Human Lung Cancer. PLoS ONE 2015, 10, e0136584. [CrossRef]

62. He, Y.; Li, H.; Chen, Y.; Li, P.; Gao, L.; Zheng, Y.; Sun, Y.; Chen, J.; Qian, X. Expression of anoctamin 1 is associated with advanced tumor stage in patients with non-small cell lung cancer and predicts recurrence after surgery. Clin. Transl. Oncol. 2017. [CrossRef]

63. Guo, S.; Chen, Y.; Pang, C.; Wang, X.; Shi, S.; Zhang, H.; An, H.; Zhan, Y. Matrine is a novel inhibitor of the TMEM16A chloride channel with antilung adenocarcinoma effects. J. Cell. Physiol. 2018. [CrossRef]

64. Deng, L.; Yang, J.; Chen, H.; Ma, B.; Pan, K.; Su, C.; Xu, F.; Zhang, J. Knockdown of TMEM16A suppressed MAPK and inhibited cell proliferation and migration in hepatocellular carcinoma. Oncol. Targets Ther. 2016, 9, 325-333.

65. Jung, I.; Gurzu, S.; Turdean, S.; Ciortea, D.; Sahlean, D.I.; Golea, M.; Bara, T. Relationship of endothelial area with VEGF-A, COX-2, maspin, c-KIT, and DOG-1 immunoreactivity in liposarcomas versus non-lipomatous soft tissue tumors. Int. J. Clin. Exp. Pathol. 2015, 8, 1776-1782. 
66. Sah, S.P.; McCluggage, W.G. DOG1 immunoreactivity in uterine leiomyosarcomas. J. Clin. Pathol. 2013, 66, 40-43. [CrossRef]

67. Abd Raboh, N.M.; Hakim, S.A. Diagnostic role of DOG1 and p63 immunohistochemistry in salivary gland carcinomas. Int. J. Clin. Exp. Pathol. 2015, 8, 9214-9222.

68. Akpalo, H.; Lange, C.; Zustin, J. Discovered on gastrointestinal stromal tumour 1 (DOG1): A useful immunohistochemical marker for diagnosing chondroblastoma. Histopathology 2012, 60, 1099-1106. [CrossRef]

69. Hemminger, J.; Iwenofu, O.H. Discovered on gastrointestinal stromal tumours 1 (DOG1) expression in non-gastrointestinal stromal tumour (GIST) neoplasms. Histopathology 2012, 61, 170-177. [CrossRef]

70. Chenevert, J.; Duvvuri, U.; Chiosea, S.; Dacic, S.; Cieply, K.; Kim, J.; Shiwarski, D.; Seethala, R.R. DOG1: A novel marker of salivary acinar and intercalated duct differentiation. Mod. Pathol. 2012, 25, 919-929. [CrossRef]

71. Stanich, J.E.; Gibbons, S.J.; Eisenman, S.T.; Bardsley, M.R.; Rock, J.R.; Harfe, B.D.; Ordog, T.; Farrugia, G. ANO1 AS A REGULATOR OF PROLIFERATION. Am. J. Physiol. Gastrointest. Liver Physiol. 2011, 301, G1044-G1051. [CrossRef]

72. Mazzone, A.; Eisenman, S.T.; Strege, P.R.; Yao, Z.; Ordog, T.; Gibbons, S.J.; Farrugia, G. Inhibition of Cell Proliferation by a Selective Inhibitor of the $\mathrm{Ca}(2+)$-activated $\mathrm{Cl}(-)$ Channel, Ano1. Biochem. Biophys. Res. Commun. 2012, 427, 248-253. [CrossRef]

73. Wanitchakool, P.; Wolf, L.; Koehl, G.; Sirianant, L.; Gaumann, A.; Schreiber, R.; Duvvuri, U.; Kunzelmann, K. Role of Anoctamins in Cancer and Apoptosis. Philos. Trans. R. Soc. Lond. B Biol. Sci. 2014, 369, 20130096. [CrossRef]

74. Bill, A.; Alex Gaither, L. The Mechanistic Role of the Calcium-Activated Chloride Channel ANO1 in Tumor Growth and Signaling. Adv. Exp. Med. Biol. 2017. [CrossRef]

75. Guan, L.; Song, Y.; Gao, J.; Gao, J.; Wang, K. Inhibition of calcium-activated chloride channel ANO1 suppresses proliferation and induces apoptosis of epithelium originated cancer cells. Oncotarget 2016, 7, 78619-78630. [CrossRef]

76. Wang, H.; Zou, L.; Ma, K.; Yu, J.; Wu, H.; Wei, M.; Xiao, Q. Cell-specific mechanisms of TMEM16A Ca2+-activated chloride channel in cancer. Mol. Cancer 2017, 16, 152. [CrossRef]

77. Ishaque, N.; Abba, M.L.; Hauser, C.; Patil, N.; Paramasivam, N.; Huebschmann, D.; Leupold, J.H.; Balasubramanian, G.P.; Kleinheinz, K.; Toprak, U.H.; et al. Whole genome sequencing puts forward hypotheses on metastasis evolution and therapy in colorectal cancer. Nat. Commun. 2018, 9, 4782. [CrossRef]

78. Hesson, L.B.; Ng, B.; Zarzour, P.; Srivastava, S.; Kwok, C.T.; Packham, D.; Nunez, A.C.; Beck, D.; Ryan, R.; Dower, A.; et al. Integrated Genetic, Epigenetic, and Transcriptional Profiling Identifies Molecular Pathways in the Development of Laterally Spreading Tumors. Mol. Cancer Res. 2016, 14, 1217-1228. [CrossRef]

79. Chang, Z.; Cai, C.; Han, D.; Gao, Y.; Li, Q.; Feng, L.; Zhang, W.; Zheng, J.; Jin, J.; Zhang, H.; et al. Anoctamin5 regulates cell migration and invasion in thyroid cancer. Int. J. Oncol. 2017, 51, 1311-1319. [CrossRef]

80. Zhao, P.; Torcaso, A.; Mariano, A.; Xu, L.; Mohsin, S.; Zhao, L.; Han, R. Anoctamin 6 Regulates C2C12 Myoblast Proliferation. PLoS ONE 2014, 9, e92749. [CrossRef]

81. Kaikkonen, E.; Rantapero, T.; Zhang, Q.; Taimen, P.; Laitinen, V.; Kallajoki, M.; Jambulingam, D.; Ettala, O.; Knaapila, J.; Bostrom, P.J.; et al. ANO7 is associated with aggressive prostate cancer. Int. J. Cancer 2018, 143, 2479-2487. [CrossRef]

82. Mohsenzadegan, M.; Shekarabi, M.; Madjd, Z.; Asgari, M.; Abolhasani, M.; Tajik, N.; Farajollahi, M.M. Study of NGEP expression pattern in cancerous tissues provides novel insights into prognostic marker in prostate cancer. Biomark. Med. 2015, 9, 391-401. [CrossRef]

83. Cereda, V.; Poole, D.J.; Palena, C.; Das, S.; Bera, T.K.; Remondo, C.; Gulley, J.L.; Arlen, P.M.; Yokokawa, J.; Pastan, I.; et al. New gene expressed in prostate: A potential target for T cell-mediated prostate cancer immunotherapy. Cancer Immunol. Immunother. 2010, 59, 63-71. [CrossRef]

84. Das, S.; Hahn, Y.; Walker, D.A.; Nagata, S.; Willingham, M.C.; Peehl, D.M.; Bera, T.K.; Lee, B.; Pastan, I. Topology of NGEP, a prostate-specific cell:cell junction protein widely expressed in many cancers of different grade level. Cancer Res. 2008, 68, 6306-6312. [CrossRef]

85. Das, S.; Hahn, Y.; Nagata, S.; Willingham, M.C.; Bera, T.K.; Lee, B.; Pastan, I. NGEP, a prostate-specific plasma membrane protein that promotes the association of LNCaP cells. Cancer Res. 2007, 67, 1594-1601. [CrossRef] 
86. Bera, T.K.; Das, S.; Maeda, H.; Beers, R.; Wolfgang, C.D.; Kumar, V.; Hahn, Y.; Lee, B.; Pastan, I. NGEP, a gene encoding a membrane protein detected only in prostate cancer and normal prostate. Proc. Natl. Acad. Sci. USA 2004, 101, 3059-3064. [CrossRef]

87. Li, Y.; Wang, X.; Vural, S.; Mishra, N.K.; Cowan, K.H.; Guda, C. Exome analysis reveals differentially mutated gene signatures of stage, grade and subtype in breast cancers. PLoS ONE 2015, 10, e0119383. [CrossRef]

88. Jun, I.; Park, H.S.; Piao, H.; Han, J.W.; An, M.J.; Yun, B.G.; Zhang, X.; Cha, Y.H.; Shin, Y.K.; Yook, J.I.; et al. ANO9/TMEM16J promotes tumourigenesis via EGFR and is a novel therapeutic target for pancreatic cancer. Br. J. Cancer 2017. [CrossRef]

89. Li, C.; Cai, S.; Wang, X.; Jiang, Z. Identification and characterization of ANO9 in stage II and III colorectal carcinoma. Oncotarget 2015, 6, 29324-29334. [CrossRef]

90. Kunzelmann, K.; Tian, Y.; Martins, J.R.; Faria, D.; Kongsuphol, P.; Ousingsawat, J.; Thevenod, F.; Roussa, E.; Rock, J.R.; Schreiber, R. Anoctamins. Pflug. Arch. 2011, 462, 195-208. [CrossRef]

91. Pedemonte, N.; Galietta, L.J. Structure and Function of TMEM16 Proteins (Anoctamins). Physiol. Rev. 2014, 94, 419-459. [CrossRef]

92. Paulino, C.; Neldner, Y.; Lam, A.K.; Kalienkova, V.; Brunner, J.D.; Schenck, S.; Dutzler, R. Structural basis for anion conduction in the calcium-activated chloride channel TMEM16A. Elife 2017, 6, e26232. [CrossRef]

93. Brunner, J.D.; Lim, N.K.; Schenck, S.; Duerst, A.; Dutzler, R. X-ray structure of a calcium-activated TMEM16 lipid scramblase. Nature 2014, 516, 207-212. [CrossRef]

94. Lee, B.C.; Khelashvili, G.; Falzone, M.; Menon, A.K.; Weinstein, H.; Accardi, A. Gating mechanism of the extracellular entry to the lipid pathway in a TMEM16 scramblase. Nat. Commun. 2018, 9, 3251. [CrossRef]

95. Schreiber, R.; Ousingsawat, J.; Wanitchakool, P.; Sirianant, L.; Benedetto, R.; Reiss, K.; Kunzelmann, K. Regulation of TMEM16A/ANO1 and TMEM16F/ANO6 ion currents and phospholipid scrambling by Ca2+ and plasma membrane lipid. J. Physiol. 2018, 596, 217-229. [CrossRef]

96. Shimizu, T.; Iehara, T.; Sato, K.; Fujii, T.; Sakai, H.; Okada, Y. TMEM16F is a component of a Ca2+-activated Cl-channel but not a volume-sensitive outwardly rectifying Cl-channel. Am. J. Physiol. Cell Physiol.. 2013, 304, C748-C759. [CrossRef]

97. Grubb, S.; Poulsen, K.A.; Juul, C.A.; Kyed, T.; Klausen, T.K.; Larsen, E.H.; Hoffmann, E.K. TMEM16F (Anoctamin 6), an anion channel of delayed Ca2+ activation. J. Gen. Physiol.. 2013, 141, 585-600. [CrossRef]

98. Ousingsawat, J.; Wanitchakool, P.; Kmit, A.; Romao, A.M.; Jantarajit, W.; Schreiber, S.; Kunzelmann, K. Anoctamin 6 mediates effects essential for innate immunity downstream of P2X7-receptors in macrophages. Nat. Commun. 2015, 6, 6245. [CrossRef]

99. Gyobu, S.; Ishihara, K.; Suzuki, J.; Segawa, K.; Nagata, S. Characterization of the scrambling domain of the TMEM16 family. Proc. Natl. Acad. Sci. USA 2017. [CrossRef]

100. Watanabe, R.; Sakuragi, T.; Noji, H.; Nagata, S. Single-molecule analysis of phospholipid scrambling by TMEM16F. Proc. Natl. Acad. Sci. USA 2018. [CrossRef]

101. Paulino, C.; Kalienkova, V.; Lam, A.K.M.; Neldner, Y.; Dutzler, R. Activation mechanism of the calcium-activated chloride channel TMEM16A revealed by cryo-EM. Nature 2017, 552, 421-425. [CrossRef]

102. Tian, Y.; Schreiber, R.; Kunzelmann, K. Anoctamins are a family of Ca2+ activated Cl-channels. J. Cell Sci. 2012, 125, 4991-4998. [CrossRef]

103. Whitlock, J.M.; Yu, K.; Cui, Y.Y.; Hartzell, H.C. Anoctamin 5/TMEM16E facilitates muscle precursor cell fusion. J. Gen. Physiol.. 2018. [CrossRef]

104. He, Q.; Halm, S.T.; Zhang, J.; Halm, D.R. Activation of the basolateral membrane Cl conductance essential for electrogenic K secretion suppresses electrogenic Cl secretion. Exp. Physiol. 2011, 96, 305-316. [CrossRef]

105. Yokoyama, T.; Takemoto, M.; Hirakawa, M.; Saino, T. Different immunohistochemical localization for TMEM16A and CFTR in acinar and ductal cells of rat major salivary glands and exocrine pancreas. Acta Histochem. 2018. [CrossRef]

106. Schreiber, R.; Faria, D.; Skryabin, B.V.; Rock, J.R.; Kunzelmann, K. Anoctamins support calcium-dependent chloride secretion by facilitating calcium signaling in adult mouse intestine. Pflüg. Arch. 2014, 467, 1203-1213. [CrossRef]

107. Benedetto, R.; Cabrita, I.; Schreiber, R.; Kunzelmann, K. TMEM16A is indispensable for basal mucus secretion in airways and intestine. FASEB J. 2019. [CrossRef] 
108. Wanitchakool, P.; Ousingsawat, J.; Sirianant, L.; Cabrita, I.; Faria, D.; Schreiber, R.; Kunzelmann, K. Cellular defects by deletion of ANO10 are due to deregulated local calcium signaling. Cell Signal. 2017, 30, 41-49. [CrossRef]

109. Hammer, C.; Wanitchakool, P.; Sirianant, L.; Papiol, S.; Monnheimer, M.; Faria, D.; Ousingsawat, J.; Schramek, N.; Schmitt, C.; Margos, G.; et al. A coding variant of ANO10, affecting volume regulation of macrophages, is associated with Borrelia seropositivity. Mol. Med. 2015, 21, 26-37. [CrossRef]

110. Cabrita, I.; Benedetto, R.; Fonseca, A.; Wanitchakool, P.; Sirianant, L.; Skryabin, B.V.; Schenk, L.K.; Pavenstadt, H.; Schreiber, R.; Kunzelmann, K. Differential effects of anoctamins on intracellular calcium signals. Faseb J. 2017, 31, 2123-2134. [CrossRef]

111. Ruppersburg, C.C.; Hartzell, H.C. The Ca2+-activated Cl- channel ANO1/TMEM16A regulates primary ciliogenesis. Mol. Biol. Cell 2014, 25, 1793-1807. [CrossRef]

112. Schreiber, R.; Kunzelmann, K. Expression of anoctamins in retinal pigment epithelium (RPE). Pflug. Arch. 2016, 468, 1921-1929. [CrossRef]

113. Forschbach, V.; Goppelt-Struebe, M.; Kunzelmann, K.; Schreiber, R.; Piedagnel, R.; Kraus, A.; Eckardt, K.U.; Buchholz, B. Anoctamin 6 is localized in the primary cilium of renal tubular cells and is involved in apoptosis-dependent cyst lumen formation. Cell Death Dis. 2015, 6, e1899. [CrossRef]

114. Buchholz, B.; Faria, D.; Schley, G.; Schreiber, R.; Eckardt, K.U.; Kunzelmann, K. Anoctamin 1 induces calcium-activated chloride secretion and tissue proliferation in polycystic kidney disease. Kidney Int. 2014, 85, 1058-1067. [CrossRef]

115. Tian, Y.; Schreiber, R.; Wanitchakool, P.; Kongsuphol, P.; Sousa, M.; Uliyakina, I.; Palma, M.; Faria, D.; Traynor-Kaplen, A.E.; Fragata, J.I.; et al. Control of TMEM16A by INO-4995 and other inositolphosphates. Br. J. Pharmacol. 2012, 168, 253-265. [CrossRef]

116. AlDehni, F.; Spitzner, M.; Martins, J.R.; Barro Soria, R.; Schreiber, R.; Kunzelmann, K. Role of bestrophin for proliferation and in epithelial to mesenchymal transition. J. Am. Soc. Nephrol. 2009, 20, 1556-1564. [CrossRef]

117. Barro Soria, R.; Spitzner, M.; Schreiber, R.; Kunzelmann, K. Bestrophin 1 enables Ca ${ }^{2+}$ activated Cl-conductance in epithelia. J. Biol. Chem. 2009, 284, 29405-29412. [CrossRef]

118. Schreiber, R.; Buchholz, B.; Kraus, A.; Schley, G.; Scholz, J.; Ousingsawat, J.; Kunzelmann, K. Lipid peroxidation drives renal cyst growth in vitro through activation of TMEM16A. J. Am. Soc. Nephrol. JASN 2019. [CrossRef]

119. Schlatter, E.; Frobe, U.; Greger, R. Ion conductances of isolated cortical collecting duct cells. Pflug. Arch. 1992, 421, 381-387. [CrossRef]

120. Morris, A.P.; Frizzell, R.A. Ca(2+)-dependent Cl-channels in undifferentiated human colonic cells (HT-29). I. Single-channel properties. Am. J. Physiol. 1993, 264, C968-C976. [CrossRef]

121. Qu, Z.; Yao, W.; Yao, R.; Liu, X.; Yu, K.; Hartzell, H.C. The Ca -activated Cl channel, ANO1 (TMEM16A), is a double-edged sword in cell proliferation and tumorigenesis. Cancer Med. 2014, 3, 453-461. [CrossRef]

122. Fujimoto, M.; Kito, H.; Kajikuri, J.; Ohya, S. Transcriptional repression of human epidermal growth factor receptor 2 by $\mathrm{ClC}-3 \mathrm{Cl}(-) / \mathrm{H}(+)$ transporter inhibition in human breast cancer cells. Cancer Sci. 2018, 109, 2781-2791. [CrossRef]

123. Almaca, J.; Tian, Y.; AlDehni, F.; Ousingsawat, J.; Kongsuphol, P.; Rock, J.R.; Harfe, B.D.; Schreiber, R.; Kunzelmann, K. TMEM16 proteins produce volume regulated chloride currents that are reduced in mice lacking TMEM16A. J. Biol. Chem. 2009, 284, 28571-28578. [CrossRef]

124. Wang, M.; Yang, H.; Zheng, L.Y.; Zhang, Z.; Tang, Y.B.; Wang, G.L.; Du, Y.H.; Lv, X.F.; Liu, J.; Zhou, J.G.; et al. Downregulation of TMEM16A Calcium-Activated Chloride Channel Contributes to Cerebrovascular Remodeling during Hypertension through Promoting Basilar Smooth Muscle Cell Proliferation. Circulation 2012, 125, 697-707. [CrossRef]

125. Allawzi, A.M.; Vang, A.; Clements, R.T.; Jhun, B.S.; Kue, N.R.; Mancini, T.J.; Landi, A.K.; Terentyev, D.; O-Uchi, J.; Comhair, S.A.; et al. Activation of Anoctamin-1 Limits Pulmonary Endothelial Cell Proliferation via p38-MAPK-dependent Apoptosis. Am. J. Respir. Cell Mol. Biol. 2017. [CrossRef]

126. Sui, Y.; Wu, F.; Lv, J.; Li, H.; Li, X.; Du, Z.; Sun, M.; Zheng, Y.; Yang, L.; Zhong, L.; et al. Identification of the Novel TMEM16A Inhibitor Dehydroandrographolide and Its Anticancer Activity on SW620 Cells. PLoS ONE 2015, 10, e0144715. [CrossRef]

127. Seo, Y.; Kim, J.; Chang, J.; Kim, S.S.; Namkung, W.; Kim, I. Synthesis and biological evaluation of novel Ani9 derivatives as potent and selective ANO1 inhibitors. Eur. J. Med. Chem. 2018, 160, 245-255. [CrossRef] 
128. Miner, K.; Labitzke, K.; Liu, B.; Elliot, R.; Wang, P.; Henckels, K.; Gaida, K.; Elliot, R.; Chen, J.J.; Liu, L.; et al. The Anthelminthic Niclosamide And Related Compounds Represent Potent Tmem16a Antagonists That Fully Relax Mouse And Human Airway Rings. Froniers Pharmacol. 2019. [CrossRef]

129. Seo, Y.; Park, J.; Kim, M.; Lee, H.K.; Kim, J.H.; Jeong, J.H.; Namkung, W. Inhibition of ANO1/TMEM16A Chloride Channel by Idebenone and Its Cytotoxicity to Cancer Cell Lines. PLoS ONE 2015, 10, e0133656. [CrossRef]

130. Wang, A.M.; Ku, H.H.; Liang, Y.C.; Chen, Y.C.; Hwu, Y.M.; Yeh, T.S. The autonomous notch signal pathway is activated by baicalin and baicalein but is suppressed by niclosamide in $\mathrm{K} 562$ cells. J. Cell Biochem. 2009, 106, 682-692. [CrossRef]

131. Meurette, O.; Mehlen, P. Notch Signaling in the Tumor Microenvironment. Cancer Cell 2018, 34, 536-548. [CrossRef]

132. Kim, S.Y.; Kang, J.W.; Song, X.; Kim, B.K.; Yoo, Y.D.; Kwon, Y.T.; Lee, Y.J. Role of the IL-6-JAK1-STAT3-Oct-4 pathway in the conversion of non-stem cancer cells into cancer stem-like cells. Cell Signal. 2013, 25, 961-969. [CrossRef]

133. Jin, Y.; Lu, Z.; Ding, K.; Li, J.; Du, X.; Chen, C.; Sun, X.; Wu, Y.; Zhou, J.; Pan, J. Antineoplastic mechanisms of niclosamide in acute myelogenous leukemia stem cells: Inactivation of the NF-kappaB pathway and generation of reactive oxygen species. Cancer Res. 2010, 70, 2516-2527. [CrossRef]

134. Ren, X.; Duan, L.; He, Q.; Zhang, Z.; Zhou, Y.; Wu, D.; Pan, J.; Pei, D.; Ding, K. Identification of Niclosamide as a New Small-Molecule Inhibitor of the STAT3 Signaling Pathway. ACS Med. Chem. Lett. 2010, 1, 454-459. [CrossRef]

135. Osada, T.; Chen, M.; Yang, X.Y.; Spasojevic, I.; Vandeusen, J.B.; Hsu, D.; Clary, B.M.; Clay, T.M.; Chen, W.; Morse, M.A.; et al. Antihelminth compound niclosamide downregulates Wnt signaling and elicits antitumor responses in tumors with activating APC mutations. Cancer Res. 2011, 71, 4172-4182. [CrossRef]

136. Wang, L.H.; Xu, M.; Fu, L.Q.; Chen, X.Y.; Yang, F. The Antihelminthic Niclosamide Inhibits Cancer Stemness, Extracellular Matrix Remodeling, and Metastasis through Dysregulation of the Nuclear beta-catenin/c-Myc axis in OSCC. Sci. Rep. 2018, 8, 12776. [CrossRef]

137. Arend, R.C.; Londono-Joshi, A.I.; Gangrade, A.; Katre, A.A.; Kurpad, C.; Li, Y.; Samant, R.S.; Li, P.K.; Landen, C.N.; Yang, E.S.; et al. Niclosamide and its analogs are potent inhibitors of Wnt/beta-catenin, mTOR and STAT3 signaling in ovarian cancer. Oncotarget 2016, 7, 86803-86815. [CrossRef]

138. Ahn, S.Y.; Yang, J.H.; Kim, N.H.; Lee, K.; Cha, Y.H.; Yun, J.S.; Kang, H.E.; Lee, Y.; Choi, J.; Kim, H.S.; et al. Anti-helminthic niclosamide inhibits Ras-driven oncogenic transformation via activation of GSK-3. Oncotarget 2017, 8, 31856-31863. [CrossRef]

139. Chen, B.; Wei, W.; Ma, L.; Yang, B.; Gill, R.M.; Chua, M.S.; Butte, A.J.; So, S. Computational Discovery of Niclosamide Ethanolamine, a Repurposed Drug Candidate That Reduces Growth of Hepatocellular Carcinoma Cells In Vitro and in Mice by Inhibiting Cell Division Cycle 37 Signaling. Gastroenterology 2017, 152, 2022-2036. [CrossRef]

140. Li, Y.; Li, P.K.; Roberts, M.J.; Arend, R.C.; Samant, R.S.; Buchsbaum, D.J. Multi-targeted therapy of cancer by niclosamide: A new application for an old drug. Cancer Lett. 2014, 349, 8-14. [CrossRef]

141. Lafkas, D.; Shelton, A.; Chiu, C.; de Leon, B.G.; Chen, Y.; Stawicki, S.S.; Siltanen, C.; Reichelt, M.; Zhou, M.; $\mathrm{Wu}, \mathrm{X}$; ; et al. Therapeutic antibodies reveal Notch control of transdifferentiation in the adult lung. Nature 2015, 528, 127-131. [CrossRef]

142. Danahay, H.; Pessotti, A.D.; Coote, J.; Montgomery, B.E.; Xia, D.; Wilson, A.; Yang, H.; Wang, Z.; Bevan, L.; Thomas, C.; et al. Notch2 is required for inflammatory cytokine-driven goblet cell metaplasia in the lung. Cell Rep. 2015, 10, 239-252. [CrossRef]

143. Kondo, M.; Tsuji, M.; Hara, K.; Arimura, K.; Yagi, O.; Tagaya, E.; Takeyama, K.; Tamaoki, J. Chloride ion transport and overexpression of TMEM16A in a guinea pig asthma model. Clin. Exp. Allergy 2017, 47, 795-804. [CrossRef]

144. Kondo, M.; Nakata, J.; Arai, N.; Izumo, T.; Tagaya, E.; Takeyama, K.; Tamaoki, J.; Nagai, A. Niflumic acid inhibits goblet cell degranulation in a guinea pig asthma model. Allergol. Int. 2012, 61, 133-142. [CrossRef]

145. Wang, Y.; Wang, S.; Wu, Y.; Ren, Y.; Li, Z.; Yao, X.; Zhang, C.; Ye, N.; Jing, C.; Dong, J.; et al. Suppression of the Growth and Invasion of Human Head and Neck Squamous Cell Carcinomas via Regulating STAT3 Signaling and the miR-21/beta-catenin Axis with HJC0152. Mol. Cancer Ther. 2017, 16, 578-590. [CrossRef] 
146. Liu, C.; Lou, W.; Zhu, Y.; Nadiminty, N.; Schwartz, C.T.; Evans, C.P.; Gao, A.C. Niclosamide inhibits androgen receptor variants expression and overcomes enzalutamide resistance in castration-resistant prostate cancer. Clin. Cancer Res. 2014, 20, 3198-3210. [CrossRef]

147. Wieland, A.; Trageser, D.; Gogolok, S.; Reinartz, R.; Hofer, H.; Keller, M.; Leinhaas, A.; Schelle, R.; Normann, S.; Klaas, L.; et al. Anticancer effects of niclosamide in human glioblastoma. Clin. Cancer Res. 2013, 19, 4124-4136. [CrossRef]

148. Schweizer, M.T.; Haugk, K.; McKiernan, J.S.; Gulati, R.; Cheng, H.H.; Maes, J.L.; Dumpit, R.F.; Nelson, P.S.; Montgomery, B.; McCune, J.S.; et al. A phase I study of niclosamide in combination with enzalutamide in men with castration-resistant prostate cancer. PLOS ONE 2018, 13, e0198389. [CrossRef]

149. Burock, S.; Daum, S.; Keilholz, U.; Neumann, K.; Walther, W.; Stein, U. Phase II trial to investigate the safety and efficacy of orally applied niclosamide in patients with metachronous or sychronous metastases of a colorectal cancer progressing after therapy: The NIKOLO trial. BMC Cancer 2018, 18, 297. [CrossRef]

150. Di Zanni, E.; Gradogna, A.; Scholz-Starke, J.; Boccaccio, A. Gain of function of TMEM16E/ANO5 scrambling activity caused by a mutation associated with gnathodiaphyseal dysplasia. Cell. Mol. Life Sci. 2017. [CrossRef]

151. Mattheij, N.J.; Braun, A.; van Kruchten, R.; Castoldi, E.; Pircher, J.; Baaten, C.C.; Wulling, M.; Kuijpers, M.J.; Kohler, R.; Poole, A.W.; et al. Survival protein anoctamin-6 controls multiple platelet responses including phospholipid scrambling, swelling, and protein cleavage. FASEB J. 2015, 30, 727-737. [CrossRef]

152. Carpenter, G. The EGF receptor: A nexus for trafficking and signaling. Bioessays 2000, 22, 697-707. [CrossRef]

153. Hodeify, R.; Yu, F.; Courjaret, R.; Nader, N.; Dib, M.; Sun, L.; Adap, E.; Hubrack, S.; Machaca, K. Regulation and Role of Store-Operated $\mathrm{Ca}(2+)$ Entry in Cellular Proliferation. In Calcium Entry Channels in Non-Excitable Cells; Kozak, J.A., Putney, J.W., Jr., Eds.; CRC Press/Taylor \& Francis: Boca Raton, FL, USA, 2018; pp. $215-240$.

154. Kunzelmann, K.; Cabrita, I.; Wanitchakool, P.; Ousingsawat, J.; Sirianant, L.; Benedetto, R.; Schreiber, R. Modulating Ca2+signals: A common theme for TMEM16, Ist2, and TMC. Pflüg. Arch. 2016, 468, 475-490. [CrossRef]

155. Benedetto, R.; Ousingsawat, J.; Wanitchakool, P.; Zhang, Y.; Holtzman, M.J.; Amaral, M.; Rock, J.R.; Schreiber, R.; Kunzelmann, K. Epithelial Chloride Transport by CFTR Requires TMEM16A. Sci. Rep. 2017, 7, 12397. [CrossRef]

156. Wolf, W.; Kilic, A.; Schrul, B.; Lorenz, H.; Schwappach, B.; Seedorf, M. Yeast Ist2 recruits the endoplasmic reticulum to the plasma membrane and creates a ribosome-free membrane microcompartment. PLoS ONE 2012, 7, e39703. [CrossRef]

157. Jin, X.; Shah, S.; Liu, Y.; Zhang, H.; Lees, M.; Fu, Z.; Lippiat, J.D.; Beech, D.J.; Sivaprasadarao, A.; Baldwin, S.A.; et al. Activation of the Cl- Channel ANO1 by Localized Calcium Signals in Nociceptive Sensory Neurons Requires Coupling with the IP3 Receptor. Sci. Signal 2013, 6, ra73. [CrossRef]

158. Jin, X.; Shah, S.; Du, X.; Zhang, H.; Gamper, N. Activation of Ca2+-activated Cl- channel ANO1 by localized Ca2+ signals. J. Physiol. 2016, 594, 19-30. [CrossRef]

159. Franklin, B.M.; Voss, S.R.; Osborn, J.L. Ion channel signaling influences cellular proliferation and phagocyte activity during axolotl tail regeneration. Mech. Dev. 2017, 146, 42-54. [CrossRef]

160. Kunzelmann, K. TMEM16, LRRC8A, bestrophin: Chloride channels controlled by Ca and cell volume. Trends Biochem. Sci. 2015, 40, 535-543. [CrossRef]

161. Agell, N.; Bachs, O.; Rocamora, N.; Villalonga, P. Modulation of the Ras/Raf/MEK/ERK pathway by Ca(2+), and calmodulin. Cell Signal. 2002, 14, 649-654. [CrossRef]

162. Darling, N.J.; Cook, S.J. The role of MAPK signalling pathways in the response to endoplasmic reticulum stress. Biochim. Biophys. Acta 2014, 1843, 2150-2163. [CrossRef]

163. Gao da, Y.; Zhang, B.L.; Leung, M.C.; Au, S.C.; Wong, P.Y.; Shum, W.W. Coupling of TRPV6 and TMEM16A in epithelial principal cells of the rat epididymis. J. Gen. Physiol.. 2016, 148, 161-182. [CrossRef]

164. Barro Soria, R.; AlDehni, F.; Almaca, J.; Witzgall, R.; Schreiber, R.; Kunzelmann, K. ER localized bestrophin1 acts as a counter-ion channel to activate Ca2+ dependent ion channels TMEM16A and SK4. Pflüg. Arch. 2009, 459, 485-497. [CrossRef]

165. Martins, J.R.; Kongsuphol, P.; Sammels, E.; Daimène, S.; AlDehni, F.; Clarke, L.; Schreiber, R.; DeSmedt, H.; Amaral, M.D.; Kunzelmann, K. F508del-CFTR increases intracellular $\mathrm{Ca}^{2+}$ signaling that causes enhanced calcium-dependent Cl-conductance in cystic fibrosis. Biochim. Biophys. Acta 2011, 1812, 1385-1392. [CrossRef] 
166. Yang, H.; Kim, A.; David, T.; Palmer, D.; Jin, T.; Tien, J.; Huang, F.; Cheng, T.; Coughlin, S.R.; Jan, Y.N.; et al. TMEM16F Forms a Ca(2+)-Activated Cation Channel Required for Lipid Scrambling in Platelets during Blood Coagulation. Cell 2012, 151, 111-122. [CrossRef]

167. Keckeis, S.; Wernecke, L.; Salchow, D.J.; Reichhart, N.; Strauss, O. Activation of a Ca2+-dependent cation conductance with properties of TRPM2 by reactive oxygen species in lens epithelial cells. Exp. Eye Res. 2017, 161, 61-70. [CrossRef]

168. Keckeis, S.; Reichhart, N.; Roubeix, C.; Strauss, O. Anoctamin2 (TMEM16B) forms the Ca(2+)-activated Cl(-) channel in the retinal pigment epithelium. Exp. Eye Res. 2017, 154, 139-150. [CrossRef]

169. Sirianant, L.; Ousingsawat, J.; Tian, Y.; Schreiber, R.; Kunzelmann, K. TMC8 (EVER2) attenuates intracellular signaling by Zn2+ and Ca2+ and suppresses activation of Cl-currents. Cell Signal. 2014, 26, 2826-2833. [CrossRef]

170. Kim, H.; Kim, H.; Lee, J.; Lee, B.; Kim, H.R.; Jung, J.; Lee, M.O.; Oh, U. Anoctamin 9/TMEM16J is a cation channel activated by cAMP/PKA signal. Cell Calcium 2018, 71, 75-85. [CrossRef]

171. Gyobu, S.; Miyata, H.; Ikawa, M.; Yamazaki, D.; Takeshima, H.; Suzuki, J.; Nagata, S. A role of TMEM16E carrying a scrambling domain in sperm motility. Mol. Cell. Biol. 2015, 36, 645-659. [CrossRef]

172. Kunzelmann, K.; Schreiber, R. Chloride secretion, anoctamin 1 and $\mathrm{Ca}^{2+}$ signaling. Channels (Austin) 2014, 8, 387-388. [CrossRef]

173. Zak, J.D.; Grimaud, J.; Li, R.C.; Lin, C.C.; Murthy, V.N. Calcium-activated chloride channels clamp odor-evoked spike activity in olfactory receptor neurons. Sci. Rep. 2018, 8, 10600. [CrossRef]

174. Malysz, J.; Gibbons, S.J.; Saravanaperumal, S.A.; Du, P.; Eisenman, S.T.; Cao, C.; Oh, U.; Saur, D.; Klein, S.; Ordog, T.; et al. Conditional genetic deletion of Ano1 in interstitial cells of Cajal impairs Ca2+ transients and slow-waves in adult mouse small intestine. Am. J. Physiol. Gastrointest. Liver Physiol. 2016. [CrossRef]

175. He, M.; Ye, W.; Wang, W.J.; Sison, E.S.; Jan, Y.N.; Jan, L.Y. Cytoplasmic Cl(-) couples membrane remodeling to epithelial morphogenesis. Proc. Natl. Acad. Sci. USA 2017, 114, e11161-e11169. [CrossRef]

176. Benedetto, R.; Sirianant, L.; Pankonien, I.; Wanitchakool, P.; Ousingsawat, J.; Cabrita, I.; Schreiber, R.; Amaral, M.; Kunzelmann, K. Relationship between TMEM16A/anoctamin 1 and LRRC8A. Pflug. Arch. 2016, 468, 1751-1763. [CrossRef]

177. Schenk, L.K.; Buchholz, B.; Henke, S.F.; Michgehl, U.; Daniel, C.; Amann, K.; Kunzelmann, K.; Pavenstadt, H.J. Nephron-specific knockout of TMEM16A leads to reduced number of glomeruli and albuminuria. Am. J. Physiol. Renal Physiol. 2018. [CrossRef]

178. Bricogne, C.; Fine, M.; Pereira, P.M.; Sung, J.; Tijani, M.; Wang, Y.; Henriques, R.; Collins, M.K.; Hilgemann, D. TMEM16F activation by $\mathrm{Ca}(2+)$ triggers plasma membrane expansion and directs PD-1 trafficking. Sci. Rep. 2019, 9, 619. [CrossRef]

179. Faria, D.; Schlatter, E.; Witzgall, R.; Grahammer, F.; Bandulik, S.; Schweda, F.; Bierer, S.; Rock, J.R.; Heitzmann, D.; Kunzelmann, K.; et al. The calcium activated chloride channel Anoctamin 1 contributes to the regulation of renal function. Kindey Int. 2014, 85, 1369-1381. [CrossRef]

180. Ousingsawat, J.; Wanitchakool, P.; Schreiber, R.; Wuelling, M.; Vortkamp, A.; Kunzelmann, K. Anoctamin 6 controls bone mineralization by activating the calcium transporter NCX1. J. Biol. Chem. 2015, 290, 6270-6280. [CrossRef]

181. Benedetto, R.; Ousingsawat, J.; Cabrita, I.; Pinto, M.; Lérias, J.R.; Wanitchakool, P.; Schreiber, R.; Kunzelmann, K. Plasma membrane localized TMEM16 proteins are indispensable for expression of CFTR. J. Mol. Med. 2019. [CrossRef]

182. Oheim, M.; Kirchhoff, F.; Stuhmer, W. Calcium microdomains in regulated exocytosis. Cell Calcium 2006, 40, 423-439. [CrossRef]

183. Chieregatti, E.; Meldolesi, J. Regulated exocytosis: New organelles for non-secretory purposes. Nat. Rev. Mol. Cell Biol. 2005, 6, 181-187. [CrossRef]

184. Jacobsen, K.S.; Zeeberg, K.; Poulsen, K.A.; Hoffmann, E.K.; Schwab, A. The role of TMEM16A (ANO1) and TMEM16F (ANO6) in cell migration. Pflug. Arch. 2013, 465, 1753-1762. [CrossRef]

185. Veit, M.; Koyro, K.I.; Ahrens, B.; Bleibaum, F.; Munz, M.; Rövekamp, H.; Andrä, J.; Schreiber, R.; Kunzelmann, K.; Sommer, A.; et al. Anoctamin-6 regulates ADAM sheddase function. Biochim. Biophys. Acta Mol. Cell Res. 2018, 1865, 1598-1610. [CrossRef] 
186. Bleibaum, F.; Sommer, A.; Veit, M.; Rabe, B.; Andrä, J.; Kunzelmann, K.; Nehls, C.; Correa, W.; Gutsmann, T.; Grötzinger, J.; et al. ADAM10 sheddase activation is controlled by cell membrane asymmetry. J. Mol. Cell. Biol. 2018. [CrossRef]

187. Sommer, A.; Kordowski, F.; Buch, J.; Maretzky, T.; Evers, A.; Andra, J.; Dusterhoft, S.; Michalek, M.; Lorenzen, I.; Somasundaram, P.; et al. Phosphatidylserine exposure is required for ADAM17 sheddase function. Nat. Commun. 2016, 7, 11523. [CrossRef]

188. Crutzen, R.; Virreira, M.; Markadieu, N.; Shlyonsky, V.; Sener, A.; Malaisse, W.J.; Beauwens, R.; Boom, A.; Golstein, P.E. Anoctamin 1 (Ano1) is required for glucose-induced membrane potential oscillations and insulin secretion by murine beta-cells. Pflug. Arch. 2015, 468, 573-591. [CrossRef]

189. Edlund, A.; Esguerra, J.L.; Wendt, A.; Flodstrom-Tullberg, M.; Eliasson, L. CFTR and Anoctamin 1 (ANO1) contribute to cAMP amplified exocytosis and insulin secretion in human and murine pancreatic beta-cells. BMC Med. 2014, 12, 87-12. [CrossRef]

190. Tian, Y.; Kongsuphol, P.; Hug, M.J.; Ousingsawat, J.; Witzgall, R.; Schreiber, R.; Kunzelmann, K. Calmodulin-dependent activation of the epithelial calcium-dependent chloride channel TMEM16A. FASEB J. 2011, 25, 1058-1068. [CrossRef]

191. Gupta, R.; Radicioni, G.; Abdelwahab, S.; Dang, H.; Carpenter, J.; Chua, M.; Mieczkowski, P.A.; Sheridan, J.; Randell, S.H.; Kesimer, M. Intercellular Communication between Airway Epithelial Cells is Mediated by Exosome-Like Vesicles. Am. J. Respir. Cell Mol. Biol. 2018. [CrossRef]

192. Whitlock, J.M.; Hartzell, H.C. Anoctamins/TMEM16 Proteins: Chloride Channels Flirting with Lipids and Extracellular Vesicles. Annu. Rev. Physiol. 2016. [CrossRef]

193. Hessvik, N.P.; Llorente, A. Current knowledge on exosome biogenesis and release. Cell. Mol. Life Sci. 2018, 75, 193-208. [CrossRef]

194. Han, T.W.; Ye, W.; Bethel, N.P.; Zubia, M.; Kim, A.; Li, K.H.; Burlingame, A.L.; Grabe, M.; Jan, Y.N.; Jan, L.Y. Chemically induced vesiculation as a platform for studying TMEM16F activity. Proc. Natl. Acad. Sci. USA 2019. [CrossRef]

195. Svenningsen, P.; Nielsen, M.R.; Marcussen, N.; Walter, S.; Jensen, B.L. TMEM16A is a Ca -activated Cl channel expressed in the renal collecting duct. Acta Physiol. 2014, 212, 166-174. [CrossRef]

196. Jimenez, A.J.; Maiuri, P.; Lafaurie-Janvore, J.; Divoux, S.; Piel, M.; Perez, F. ESCRT machinery is required for plasma membrane repair. Science 2014, 343, 1247136. [CrossRef]

197. Gong, Y.N.; Guy, C.; Olauson, H.; Becker, J.U.; Yang, M.; Fitzgerald, P.; Linkermann, A.; Green, D.R. ESCRT-III Acts Downstream of MLKL to Regulate Necroptotic Cell Death and Its Consequences. Cell 2017, 169, 286-300.e216. [CrossRef]

198. Bolduc, V.; Marlow, G.; Boycott, K.M.; Saleki, K.; Inoue, H.; Kroon, J.; Itakura, M.; Robitaille, Y.; Parent, L.; Baas, F.; et al. Recessive mutations in the putative calcium-activated chloride channel Anoctamin 5 cause proximal LGMD2L and distal MMD3 muscular dystrophies. Am. J. Hum. Genet. 2010, 86, 213-221. [CrossRef]

199. Ousingsawat, J.; Cabrita, I.; Wanitchakool, P.; Sirianant, L.; Krautwald, S.; Linkermann, A.; Schreiber, R.; Kunzelmann, ${\mathrm{K} . \mathrm{Ca}^{2+}}^{2+}$ signals, cell membrane disintegration, and activation of TMEM16F during necroptosis. Cell. Mol. Life Sci. 2016. [CrossRef]

200. Sirianant, L.; Ousingsawat, J.; Wanitchakool, P.; Schreiber, R.; Kunzelmann, K. Cellular Volume regulation by Anoctamin 6:Ca2+, phospholipase A2,osmosensing. Pflüg. Arch. 2015, 468, 335-349. [CrossRef]

201. Yu, H.; Lee, H.; Herrmann, A.; Buettner, R.; Jove, R. Revisiting STAT3 signalling in cancer: New and unexpected biological functions. Nat. Rev. Cancer 2014, 14, 736-746. [CrossRef]

202. Pfitzner, E.; Kliem, S.; Baus, D.; Litterst, C.M. The role of STATs in inflammation and inflammatory diseases. Curr. Pharm. Des. 2004, 10, 2839-2850. [CrossRef]

203. Nussinov, R.; Tsai, C.J.; Jang, H. Oncogenic Ras Isoforms Signaling Specificity at the Membrane. Cancer Res. 2018, 78, 593-602. [CrossRef]

204. Galietta, L.J.; Pagesy, P.; Folli, C.; Caci, E.; Romio, L.; Costes, B.; Nicolis, E.; Cabrini, G.; Goossens, M.; Ravazzolo, R.; et al. IL-4 Is a Potent Modulator of Ion Transport in the Human Bronchial Epithelium In Vitro. J. Immunol. 2002, 168, 839-845. [CrossRef]

205. Huang, F.; Zhang, H.; Wu, M.; Yang, H.; Kudo, M.; Peters, C.J.; Woodruff, P.G.; Solberg, O.D.; Donne, M.L.; Huang, X.; et al. Calcium-activated chloride channel TMEM16A modulates mucin secretion and airway smooth muscle contraction. Proc. Natl. Acad. Sci. USA 2012, 109, 16354-16359. [CrossRef] 
206. Caci, E.; Scudieri, P.; Di Carlo, E.; Morelli, P.; Bruno, S.; De, F.I.; Bragonzi, A.; Gianotti, A.; Sondo, E.; Ferrera, L.; et al. Upregulation of TMEM16A Protein in Bronchial Epithelial Cells by Bacterial Pyocyanin. PLoS ONE 2015, 10, e0131775. [CrossRef]

207. Scudieri, P.; Caci, E.; Bruno, S.; Ferrera, L.; Schiavon, M.; Sondo, E.; Tomati, V.; Gianotti, A.; Zegarra-Moran, O.; Pedemonte, N.; et al. Association of TMEM16A chloride channel overexpression with airway goblet cells metaplasia. J. Physiol. 2012, 590, 6141-6155. [CrossRef]

208. Landen, N.X.; Li, D.; Stahle, M. Transition from inflammation to proliferation: A critical step during wound healing. Cell. Mol. Life Sci. 2016, 73, 3861-3885. [CrossRef]

209. Lang, F.; Hoffmann, E.K. CrossTalk proposal: Cell volume changes are an essential step in the cell death machinery. J. Physiol. 2013, 591, 6119-6121. [CrossRef]

210. Hoffmann, E.K.; Lambert, I.H.; Pedersen, S.F. Physiology of cell volume regulation in vertebrates. Physiol. Rev. 2009, 89, 193-277. [CrossRef]

211. Lee, E.L.; Shimizu, T.; Ise, T.; Numata, T.; Kohno, K.; Okada, Y. Impaired activity of volume-sensitive Clchannel is involved in cisplatin resistance of cancer cells. J. Cell. Physiol. 2007, 211, 513-521. [CrossRef]

212. Okada, Y.; Shimizu, T.; Maeno, E.; Tanabe, S.; Wang, X.; Takahashi, N. Volume-sensitive chloride channels involved in apoptotic volume decrease and cell death. J. Membr. Biol. 2006, 209, 21-29. [CrossRef] [PubMed]

213. Shimizu, T.; Lee, E.L.; Ise, T.; Okada, Y. Volume-sensitive $\mathrm{Cl}(-)$ channel as a regulator of acquired cisplatin resistance. Anticancer Res. 2008, 28, 75-83. [PubMed]

214. Lemonnier, L.; Shuba, Y.; Crepin, A.; Roudbaraki, M.; Slomianny, C.; Mauroy, B.; Nilius, B.; Prevarskaya, N.; Skryma, R. Bcl-2-dependent modulation of swelling-activated Cl- current and $\mathrm{ClC}-3$ expression in human prostate cancer epithelial cells. Cancer Res. 2004, 64, 4841-4848. [CrossRef] [PubMed]

215. Planells-Cases, R.; Lutter, D.; Guyader, C.; Gerhards, N.M.; Ullrich, F.; Elger, D.A.; Kucukosmanoglu, A.; Xu, G.; Voss, F.K.; Reincke, S.M.; et al. Subunit composition of VRAC channels determines substrate specificity and cellular resistance to Pt-based anti-cancer drugs. EMBO J. 2015, 34, 2993-3008. [CrossRef] [PubMed]

216. Pedersen, S.F.; Okada, Y.; Nilius, B. Biophysics and Physiology of the Volume-Regulated Anion Channel (VRAC)/Volume-Sensitive Outwardly Rectifying Anion Channel (VSOR). Pflug. Arch. 2016, 468, 371-383. [CrossRef] [PubMed]

217. Lang, F.; Foller, M.; Lang, K.; Lang, P.; Ritter, M.; Vereninov, A.; Szabo, I.; Huber, S.M.; Gulbins, E. Cell volume regulatory ion channels in cell proliferation and cell death. Methods Enzymol. 2007, 428, $209-225$. [PubMed]

218. Juul, C.A.; Grubb, S.; Poulsen, K.A.; Kyed, T.; Hashem, N.; Lambert, I.H.; Larsen, E.H.; Hoffmann, E.K. Anoctamin 6 differs from VRAC and VSOAC but is involved in apoptosis and supports volume regulation in the presence of Ca. Pflug. Arch. 2014, 466, 1899-1910. [CrossRef] [PubMed]

219. Qiu, Z.; Dubin, A.E.; Mathur, J.; Tu, B.; Reddy, K.; Miraglia, L.J.; Reinhardt, J.; Orth, A.P.; Patapoutian, A. SWELL1, a Plasma Membrane Protein, Is an Essential Component of Volume-Regulated Anion Channel. Cell 2014, 157, 447-458. [CrossRef]

220. Voss, F.K.; Ullrich, F.; Munch, J.; Lazarow, K.; Lutter, D.; Mah, N.; Andrade-Navarro, M.A.; von Kries, J.P.; Stauber, T.; Jentsch, T.J. Identification of LRRC8 Heteromers as an Essential Component of the Volume-Regulated Anion Channel VRAC. Science 2014, 344, 634-638. [CrossRef]

221. Pedersen, S.F.; Klausen, T.K.; Nilius, B. The identification of VRAC (Volume Regulated Anion Channel):An amazing Odyssey. Acta Physiol. 2015, 213, 868-881. [CrossRef]

222. Deneka, D.; Sawicka, M.; Lam, A.K.M.; Paulino, C.; Dutzler, R. Structure of a volume-regulated anion channel of the LRRC8 family. Nature 2018, 558, 254-259. [CrossRef]

223. Kefauver, J.M.; Saotome, K.; Dubin, A.E.; Pallesen, J.; Cottrell, C.A.; Cahalan, S.M.; Qiu, Z.; Hong, G.; Crowley, C.S.; Whitwam, T.; et al. Structure of the human volume regulated anion channel. Elife 2018, 7, e38461. [CrossRef]

224. Kasuya, G.; Nakane, T.; Yokoyama, T.; Jia, Y.; Inoue, M.; Watanabe, K.; Nakamura, R.; Nishizawa, T.; Kusakizako, T.; Tsutsumi, A.; et al. Cryo-EM structures of the human volume-regulated anion channel LRRC8. Nat. Struct. Mol. Biol. 2018, 25, 797-804. [CrossRef]

225. Sirianant, L.; Wanitchakool, P.; Ousingsawat, J.; Benedetto, R.; Zormpa, A.; Cabrita, I.; Schreiber, R.; Kunzelmann, K. Non-essential contribution of LRRC8A to volume regulation. Pflüg. Arch. 2016, 468, 1789-1796. [CrossRef] 
226. Milenkovic, A.; Brandl, C.; Milenkovic, V.M.; Jendrike, T.; Sirianant, L.; Wanitchakool, P.; Zimmermann, S.; Reif, C.M.; Horling, F.; Schrewe, H.; et al. Bestrophin1 is the volume-regulated anion channel in mouse sperm and human retinal pigment epithelium. Proc. Natl. Acad. Sci. USA 2015, 112, E2630-E2639. [CrossRef]

227. Wanitchakool, P.; Ousingsawat, J.; Sirianant, L.; MacAulay, N.; Schreiber, R.; Kunzelmann, K. Cl-channels in apoptosis. Eur. Biophys. J. 2016, 45, 599-610. [CrossRef]

228. Kumar, L.; Chou, J.; Yee, C.S.; Borzutzky, A.; Vollmann, E.H.; von Andrian, U.H.; Park, S.Y.; Hollander, G.; Manis, J.P.; Poliani, P.L.; et al. Leucine-rich repeat containing 8A (LRRC8A) is essential for T lymphocyte development and function. J. Exp. Med. 2014, 211, 929-942. [CrossRef]

229. Yamada, T.; Wondergem, R.; Morrison, R.; Yin, V.P.; Strange, K. Leucine-rich repeat containing protein LRRC8A is essential for swelling-activated Cl-currents and embryonic development in zebrafish. Physiol. Rep. 2016, 4. [CrossRef]

230. Sawada, A.; Takihara, Y.; Kim, J.Y.; Matsuda-Hashii, Y.; Tokimasa, S.; Fujisaki, H.; Kubota, K.; Endo, H.; Onodera, T.; Ohta, H.; et al. A congenital mutation of the novel gene LRRC8 causes agammaglobulinemia in humans. J. Clin. Investig. 2003, 112, 1707-1713. [CrossRef]

231. Bao, J.; Perez, C.J.; Kim, J.; Zhang, H.; Murphy, C.J.; Hamidi, T.; Jaubert, J.; Platt, C.D.; Chou, J.; Deng, M.; et al. Deficient LRRC8A-dependent volume-regulated anion channel activity is associated with male infertility in mice. JCI Insight 2018, 3, e99767. [CrossRef]

232. Lemonnier, L.; Prevarskaya, N.; Shuba, Y.; Vanden Abeele, F.; Nilius, B.; Mazurier, J.; Skryma, R. Ca2+ modulation of volume-regulated anion channels: Evidence for colocalization with store-operated channels. FASEB J. 2002, 16, 222-224. [CrossRef]

233. Zholos, A.; Beck, B.; Sydorenko, V.; Lemonnier, L.; Bordat, P.; Prevarskaya, N.; Skryma, R. Ca(2+)- and volume-sensitive chloride currents are differentially regulated by agonists and store-operated Ca2+ entry. $J$. Gen. Physiol. 2005, 125, 197-211. [CrossRef]

234. Zhang, H.; Deng, Z.; Zhang, D.; Li, H.; Zhang, L.; Niu, J.; Zuo, W.; Fu, R.; Fan, L.; Ye, J.H.; et al. High expression of leucinerich repeatcontaining $8 \mathrm{~A}$ is indicative of a worse outcome of colon cancer patients by enhancing cancer cell growth and metastasis. Oncol. Rep. 2018, 40, 1275-1286.

235. Sorensen, B.H.; Nielsen, D.; Thorsteinsdottir, U.A.; Hoffmann, E.K.; Lambert, I.H. Downregulation of LRRC8A protects human ovarian and alveolar carcinoma cells against Cisplatin-induced expression of p53, MDM2, p21Waf1/Cip1, and Caspase-9/-3 activation. Am. J. Physiol. Cell Physiol. 2016, 310, C857-C873. [CrossRef]

236. Ghosh, A.; Khandelwal, N.; Kumar, A.; Bera, A.K. Leucine-rich repeat-containing 8B protein is associated with the endoplasmic reticulum Ca2+ leak in HEK293 cells. J. Cell Sci. 2017, 130, 3818-3828. [CrossRef]

237. Borahay, M.A.; Kilic, G.S.; Yallampalli, C.; Snyder, R.R.; Hankins, G.D.; Al-Hendy, A.; Boehning, D. Simvastatin potently induces calcium-dependent apoptosis of human leiomyoma cells. J. Biol. Chem. 2014, 289, 35075-35086. [CrossRef]

238. Jackisch, C.; Hahm, H.A.; Tombal, B.; McCloskey, D.; Butash, K.; Davidson, N.E.; Denmeade, S.R. Delayed micromolar elevation in intracellular calcium precedes induction of apoptosis in thapsigargin-treated breast cancer cells. Clin. Cancer Res. 2000, 6, 2844-2850.

239. Martins, J.R.; Faria, D.; Kongsuphol, P.; Reisch, B.; Schreiber, R.; Kunzelmann, K. Anoctamin 6 is an essential component of the outwardly rectifying chloride channel. Proc. Natl. Acad. Sci. USA 2011, 108, 18168-18172. [CrossRef]

240. Szabo, I.; Lepple-Wienhues, A.; Kaba, K.N.; Zoratti, M.; Gulbins, E.; Lang, F. Tyrosine kinase-dependent activation of a chloride channel in CD95-induced apoptosis in T lymphocytes. Proc. Natl. Acad. Sci. USA 1998, 95, 6169-6174. [CrossRef]

241. Lepple-Wienhues, A.; Wieland, U.; Laun, T.; Heil, L.; Stern, M.; Lang, F. A src-like kinase activates outwardly rectifying chloride channels in CFTR-defective lymphocytes. FASEB J. 2001, 15, 927-931. [CrossRef]

242. Lian, H.; Cheng, Y.; Wu, X. TMEM16A exacerbates renal injury by activating P38/JNK signaling pathway to promote podocyte apoptosis in diabetic nephropathy mice. Biochem. Biophys. Res. Commun. 2017. [CrossRef]

243. Zeng, J.W.; Chen, B.Y.; Lv, X.F.; Sun, L.; Zeng, X.L.; Zheng, H.Q.; Du, Y.H.; Wang, G.L.; Ma, M.M.; Guan, Y.Y. TMEM16A Participates in Hydrogen Peroxide-Induced Apoptosis by Facilitating Mitochondria-Dependent Pathway in Vascular Smooth Muscle Cells. Br. J. Pharmacol. 2018. [CrossRef]

244. Henkel, B.; Drose, D.R.; Ackels, T.; Oberland, S.; Spehr, M.; Neuhaus, E.M. Co-expression of Anoctamins in Cilia of Olfactory Sensory Neurons. Chem. Sens. 2015, 40, 73-87. [CrossRef] 
245. Linkermann, A.; Stockwell, B.R.; Krautwald, S.; Anders, H.J. Regulated cell death and inflammation: An auto-amplification loop causes organ failure. Nat. Rev. Immunol. 2014, 14, 759-767. [CrossRef]

246. Ousingsawat, J.; Wanitchakool, P.; Schreiber, R.; Kunzelmann, K. Contribution of TMEM16F to pyroptotic cell death. Cell Death Dis. 2018, 9, 300. [CrossRef]

247. Simoes, F.; Ousingsawat, J.; Wanitchakool, P.; Fonseca, A.; Cabrita, I.; Benedetto, R.; Schreiber, R.; Kunzelmann, K. CFTR supports cell death through ROS-dependent activation of TMEM16F (anoctamin 6). Pflug. Arch. 2018, 470, 305-314. [CrossRef]

248. Kunzelmann, K. Ion channels in regulated cell death. Cell. Mol. Life Sci. 2016, 73, 2387-2403. [CrossRef]

249. Orsolic, N. Bee venom in cancer therapy. Cancer Metastasis Rev. 2012, 31, 173-194. [CrossRef]

250. Zheng, J.; Lee, H.L.; Ham, Y.W.; Song, H.S.; Song, M.J.; Hong, J.T. Anti-cancer effect of bee venom on colon cancer cell growth by activation of death receptors and inhibition of nuclear factor kappa B. Oncotarget 2015, 6, 44437-44451. [CrossRef]

251. Park, M.H.; Choi, M.S.; Kwak, D.H.; Oh, K.W.; Yoon, D.Y.; Han, S.B.; Song, H.S.; Song, M.J.; Hong, J.T. Anti-cancer effect of bee venom in prostate cancer cells through activation of caspase pathway via inactivation of NF-kappaB. Prostate 2011, 71, 801-812. [CrossRef]

252. Dar, H.H.; Tyurina, Y.Y.; Mikulska-Ruminska, K.; Shrivastava, I.; Ting, H.C.; Tyurin, V.A.; Krieger, J.; St Croix, C.M.; Watkins, S.; Bayir, E.; et al. Pseudomonas aeruginosa utilizes host polyunsaturated phosphatidylethanolamines to trigger theft-ferroptosis in bronchial epithelium. J. Clin. Investig. 2018. [CrossRef]

253. Gueraud, F.; Atalay, M.; Bresgen, N.; Cipak, A.; Eckl, P.M.; Huc, L.; Jouanin, I.; Siems, W.; Uchida, K. Chemistry and biochemistry of lipid peroxidation products. Free Radic. Res. 2010, 44, 1098-1124. [CrossRef]

254. Stockwell, B.R.; Friedmann Angeli, J.P.; Bayir, H.; Bush, A.I.; Conrad, M.; Dixon, S.J.; Fulda, S.; Gascon, S.; Hatzios, S.K.; Kagan, V.E.; et al. Ferroptosis: A Regulated Cell Death Nexus Linking Metabolism, Redox Biology, and Disease. Cell 2017, 171, 273-285. [CrossRef]

255. Yang, W.S.; SriRamaratnam, R.; Welsch, M.E.; Shimada, K.; Skouta, R.; Viswanathan, V.S.; Cheah, J.H.; Clemons, P.A.; Shamji, A.F.; Clish, C.B.; et al. Regulation of ferroptotic cancer cell death by GPX4. Cell 2014, 156, 317-331. [CrossRef]

256. Florean, C.; Song, S.; Dicato, M.; Diederich, M. Redox biology of regulated cell death in cancer: A focus on necroptosis and ferroptosis. Free Radic. Biol. Med. 2019. [CrossRef]

257. Moreira, J.D.; Hamraz, M.; Abolhassani, M.; Bigan, E.; Peres, S.; Pauleve, L.; Nogueira, M.L.; Steyaert, J.M.; Schwartz, L. The Redox Status of Cancer Cells Supports Mechanisms behind the Warburg Effect. Metabolites 2016, 6, 33. [CrossRef]

258. Dixon, S.J.; Stockwell, B.R. The role of iron and reactive oxygen species in cell death. Nat. Chem. Biol. 2014, 10, 9-17. [CrossRef]

259. Pei, S.; Minhajuddin, M.; Callahan, K.P.; Balys, M.; Ashton, J.M.; Neering, S.J.; Lagadinou, E.D.; Corbett, C.; Ye, H.; Liesveld, J.L.; et al. Targeting aberrant glutathione metabolism to eradicate human acute myelogenous leukemia cells. J. Biol. Chem. 2013, 288, 33542-33558. [CrossRef]

260. Trachootham, D.; Zhou, Y.; Zhang, H.; Demizu, Y.; Chen, Z.; Pelicano, H.; Chiao, P.J.; Achanta, G.; Arlinghaus, R.B.; Liu, J.; et al. Selective killing of oncogenically transformed cells through a ROS-mediated mechanism by beta-phenylethyl isothiocyanate. Cancer Cell 2006, 10, 241-252. [CrossRef]

261. Takeshita, N.; Evangelinos, M.; Zhou, L.; Serizawa, T.; Somera-Fajardo, R.A.; Lu, L.; Takaya, N.; Nienhaus, G.U.; Fischer, R. Pulses of Ca2+ coordinate actin assembly and exocytosis for stepwise cell extension. Proc. Natl. Acad. Sci. USA 2017, 114, 5701-5706. [CrossRef]

262. Dolma, S.; Lessnick, S.L.; Hahn, W.C.; Stockwell, B.R. Identification of genotype-selective antitumor agents using synthetic lethal chemical screening in engineered human tumor cells. Cancer Cell 2003, 3, 285-296. [CrossRef]

(C) 2019 by the authors. Licensee MDPI, Basel, Switzerland. This article is an open access article distributed under the terms and conditions of the Creative Commons Attribution (CC BY) license (http://creativecommons.org/licenses/by/4.0/). 